\title{
Ocena zgodności z Konstytucją RP niektórych przepisów ustawy o prawie autorskim i prawach pokrewnych ${ }^{1}$
}

Podlegające ocenie Trybunału Konstytucyjnego przepisy dotyczą zakresu, w jakim uprawniony, którego autorskie prawa majątkowe zostały naruszone, może żądać od osoby naruszającej te prawa naprawienia wyrządzonej szkody przez zapłatę sumy pieniężnej w wysokości odpowiadającej dwukrotności stosownego wynagrodzenia, które w chwili jego dochodzenia byłoby należne tytułem udzielenia przez uprawnionego zgody na korzystanie z utworu. Sąd Najwyższy w swoim pytaniu prawnym zakwestionował konstytucyjność jednego z przepisów ustawy w zakresie „,w jakim nakłada on obowiązek zapłaty dwukrotności stosownego wynagrodzenia na rzecz podmiotu uprawnionego z tytułu majątkowych praw autorskich". W projekcie stanowiska Sejmu oceniono, że omawiany artykuł jest zgodny z Konstytucją.

Słowa kluczowe: prawo autorskie, sąd, Trybunał Konstytucyjny

Assessment of conformity to the Constitution of certain provisions of the Act on Copyright and Related Rights:The provisions subject to the assessment of the Constitutional Tribunal concern the extent to which the rightholder, whose copyrights have been infringed, may require the person who infringed those rights to repair the damage by payment of a sum of money in the amount equivalent to two times of an appropriate salary, which would be due because of the authorized person's consent to use the work. In its question of law, the Supreme Court questioned the claimed a nonconformity to the Constitution of provisions of the Act to the extent that it "imposes an obligation to pay twice the appropriate remuneration to the entity entitled under the economic copyright". In the draft position of the Sejm it has been claimed, that the provision mentioned above conforms to the Constitution.

Keywords: copyright law, court, Constitutional Court

Doktor nauk prawnych • jbucinska@op.pl • https://orcid.org/0000-0002-2643-1437

Na podstawie art. 69 ust. 2 w związku z art. 42 pkt 3 ustawy z dnia 30 listopada 2016 r. o organizacji i trybie postępowania przed Trybunałem Konstytucyjnym (Dz. U. poz. 2072, ze zm.), w imieniu Sejmu Rzeczypospolitej Polskiej przedkładam stanowisko w sprawie pytania prawnego Sądu Najwyższego Izba Cywilna z 14 czerwca 2019 r. (sygn. akt P 14/19), jednocześnie wnosząc o uznanie, że art. 79 ust. 1 pkt 3 lit. b ustawy z dnia 4 lutego 1994 r. o prawie autorskim i prawach pokrewnych (t.j. Dz. U. 2019, poz. 1231, ze zm.) w zakresie, w jakim

$1 \quad$ Projekt stanowiska Sejmu w sprawie sygn. akt P 14/19, sporządzony 31 października 2019 r.; BAS-WAKU 1429/19. Niniejszy projekt stanowiska został sporządzony na podstawie projektu stanowiska w sprawie o sygn. akt SK 26/18 z 26 marca 2019 r. autorstwa Agnieszki Tomaszewskiej, BAS-WAKU 2757/18. 
uprawniony, którego autorskie prawa majątkowe zostały naruszone, może żądać od osoby, która naruszyła te prawa, naprawienia wyrządzonej szkody przez zapłatę sumy pieniężnej w wysokości odpowiadającej dwukrotności stosownego wynagrodzenia, które w chwili jego dochodzenia byłoby należne tytułem udzielenia przez uprawnionego zgody na korzystanie z utworu, jest zgodny z art. 64 ust. $1 \mathrm{w}$ związku z art. 31 ust. 3 w związku z art. 2 Konstytucji.

Ponadto Sejm wnosi o umorzenie postępowania w pozostałym zakresie na podstawie art. 59 ust. 1 pkt 2 ustawy o organizacji i trybie postępowania przed Trybunałem Konstytucyjnym ze względu na niedopuszczalność wydania wyroku.

\section{Uzasadnienie}

\section{Przedmiot kontroli}

1. W dniu 1 lipca 2019 r. do Kancelarii Sejmu wpłynęło zawiadomienie Prezes Trybunału Konstytucyjnego o wszczęciu postępowania przed Trybunałem Konstytucyjnym w sprawie pytania prawnego Sądu Najwyższego Izba Cywilna (dalej: Sąd Najwyższy, sąd pytający) z 14 czerwca 2019 r. (sygn. akt P 14/19).

Przedmiotem kontroli jest art. 79 ust. 1 pkt 3 lit. b ustawy z dnia 4 lutego 1994 r. o prawie autorskim i prawach pokrewnych (t.j. Dz. U. 2019, poz. 1231, ze zm.; dalej: ustawa o prawie autorskim i prawach pokrewnych, prawo autorskie lub u.p.a.).

2. Kwestionowany przepis określa roszczenia $\mathrm{z}$ tytułu naruszenia praw autorskich.

Zgodnie z art. 79 ust. 1 pkt 3 lit. b u.p.a.: „1. Uprawniony, którego autorskie prawa majątkowe zostały naruszone, może żądać od osoby, która naruszyła te prawa: [...] 3) naprawienia wyrządzonej szkody: [...] b) poprzez zapłatę sumy pieniężnej w wysokości odpowiadającej dwukrotności, a w przypadku gdy naruszenie jest zawinione - trzykrotności stosownego wynagrodzenia, które w chwili jego dochodzenia byłoby należne tytułem udzielenia przez uprawnionego zgody na korzystanie z utworu".

Sąd Najwyższy kwestionuje konstytucyjność art. 79 ust. 1 pkt 3 lit. b u.p.a. w zakresie, „w jakim nakłada on obowiązek zapłaty dwukrotności stosownego wynagrodzenia na rzecz podmiotu uprawnionego $\mathrm{z}$ tytułu majątkowych praw autorskich".

3. Zaznaczyć należy, że kwestionowany przepis prawa autorskiego był już przedmiotem kontroli Trybunału Konstytucyjnego. Utracił on moc z dniem 1 lipca 2015 r. w zakresie, w jakim uprawniony, którego autorskie prawa majątkowe zostały naruszone, mógł żądać od osoby, która naruszyła te prawa, naprawienia wyrządzonej szkody przez zapłatę sumy pieniężnej w wysokości odpowiadającej - w przypadku gdy naruszenie jest zawinione - trzykrotności stosownego wynagrodzenia, które w chwili jego dochodzenia byłoby należne tytułem udzielenia przez uprawnionego zgody na korzystanie z utworu, na podstawie wyroku TK z 23 czerwca 2015 r., sygn. akt SK 32/14. 


\section{Stan faktyczny i zarzuty sądu pytającego}

1. Pytanie o zgodność art. 79 ust. 1 pkt 3 lit. b u.p.a. z Konstytucją powstało w związku z następującym stanem faktycznym.

Spółka z ograniczoną odpowiedzialnością z siedzibą w Marciszowie (dalej: pozwany) jest operatorem telewizji kablowej, który reemitował utwory audiowizualne bez umowy licencyjnej ze Stowarzyszeniem Filmowców Polskich w Warszawie (dalej także: SFP) - organizacją zbiorowego zarządu w zakresie praw autorskich do utworów audiowizualnych - posiadającą uprawnienie do dysponowania prawami do reemisji i do dochodzenia wynagrodzenia od operatorów kablowych. Wyrokiem z 2 marca 2017 r. Sąd Okręgowy w Jeleniej Górze zakazał stronie pozwanej dokonywania reemisji w sieci telewizji kablowej utworów audiowizualnych nadawanych $\mathrm{w}$ programach telewizyjnych do czasu zawarcia z SFP umowy licencyjnej oraz zasądził od strony pozwanej na rzecz strony powodowej odszkodowanie w wysokości dwukrotnego wynagrodzenia za okres od maja 2015 r. do 31 grudnia 2015 r. Sąd Okręgowy w Jeleniej Górze podkreślił, że utrata mocy obowiązującej (w wyniku wyroku TK z 23 czerwca 2015 r., sygn. akt SK 32/14) art. 79 ust. 1 pkt 3 lit. b u.p.a. w zakresie przewidującym naprawienie szkody przez zasądzenie trzykrotności stosownego wynagrodzenia nie spowodowała utraty tej mocy w pozostałym zakresie, a zatem w tej części, w jakiej przewiduje on obowiązek zapłaty sumy pieniężnej odpowiadającej dwukrotności stosownego wynagrodzenia.

Apelacja strony pozwanej została oddalona przez Sąd Apelacyjny we Wrocławiu wyrokiem z 13 września 2017 r. Zdaniem Sądu Apelacyjnego we Wrocławiu zasadnie orzeczony został wobec pozwanego zakaz reemisji utworów do czasu zawarcia stosownej umowy licencyjnej, z powodu dopuszczenia się przez niego bezprawnego działania. Odnosząc się do kwestii zasądzenia przez Sąd Okręgowy w Jeleniej Górze odszkodowania odpowiadającego podwójnej wysokości wynagrodzenia, o jakim mowa w art. 79 ust. 1 pkt 3 lit. b u.p.a., Sąd Apelacyjny we Wrocławiu wskazał, że możliwość przyznania powodowi odszkodowania odpowiadającego podwójnej wysokości stosownego wynagrodzenia nie została wykluczona przez Trybunał Konstytucyjny w wyroku z 23 czerwca 2015 r. (sygn. akt SK 32/14). Ponadto Sąd Apelacyjny we Wrocławiu nie znalazł podstaw do kwestionowania konstytucyjności art. 79 ust. 1 pkt 3 lit. b u.p.a. w zakresie, w którym przepis ten nadal obowiązuje. Zdaniem Sądu Apelacyjnego we Wrocławiu specyfika niektórych deliktów może uzasadniać ustanowienie innych, szczególnych zasad ochrony podmiotu uprawnionego, odbiegających od ogólnych zasad przyjętych w Kodeksie cywilnym, oraz stwierdził, że taka sytuacja ma miejsce właśnie $\mathrm{w}$ przypadku naruszenia praw autorskich. $\mathrm{Z}$ tych powodów zaniechał wystąpienia do Trybunału Konstytucyjnego z pytaniem prawnym (jak domagał się pozwany).

Od powyższego wyroku pozwany złożył skargę kasacyjną do Sądu Najwyższego. Rozpoznając skargę, Sąd Najwyższy powziął wątpliwości, czy art. 79 ust. 1 
pkt 3 lit. b u.p.a. „w zakresie, w jakim uprawniony, którego autorskie prawa majątkowe zostały naruszone może żądać od osoby, która naruszyła te prawa, naprawienia wyrządzonej szkody poprzez zapłatę sumy pieniężnej w wysokości odpowiadającej dwukrotności stosownego wynagrodzenia, które w chwili jego dochodzenia byłoby należne tytułem udzielenia przez uprawnionego zgody na korzystanie z utworu, jest zgodny z art. 64 ust. 1 i 2 w związku z art. 31 ust. 3 w związku z art. 2 Konstytucji”.

2. Jak wskazuje Sąd Najwyższy, udzielenie odpowiedzi na powyższe pytanie prawne ,jest niezbędne do rozstrzygnięcia rozpoznawanej przez Sąd Najwyższy sprawy z dwóch względów. Po pierwsze, jedną z najistotniejszych kwestii stanowiącej oś sporu pomiędzy stronami niniejszego procesu, jest dopuszczalność zasądzenia na rzecz Stowarzyszenia Filmowców Polskich jako organizacji zbiorowego zarządzania prawami autorskimi lub prawami pokrewnymi, o jakiej aktualnie mowa w art. 3 pkt 2 ustawy z dnia 15 czerwca 2018 r. o zbiorowym zarządzaniu prawami autorskimi [i] prawami pokrewnymi (Dz. U. 2018, poz. 1293), a poprzednio w art. 104 ustawy o prawie autorskim i prawach pokrewnych, odszkodowania w postaci sumy pieniężnej w wysokości odpowiadającej dwukrotności stosownego wynagrodzenia, które w chwili jego dochodzenia byłoby należne tytułem udzielenia przez uprawnionego zgody na korzystanie z utworu" (pytanie prawne, s. 13).

Po drugie, problem zgodności z Konstytucją art. 79 ust. 3 lit. b u.p.a. we wskazanym zakresie „nie został wyczerpany i ostatecznie rozstrzygnięty w wyroku Trybunału Konstytucyjnego z dnia 23 czerwca 2015 r. (SK 32/14), ani też w wyroku Trybunału Sprawiedliwości Unii Europejskiej z dnia 25 stycznia 2017 r. (C-367/15) wydanym na skutek pytania prejudycjalnego z dnia 15 maja 2015 r. przedstawionego przez Sąd Najwyższy (V CSK 41/14)" (pytanie prawne, s. 14). W dalszym ciągu istnieją wątpliwości natury konstytucyjnej odnośnie do regulacji zawartej w art. 79 ust. 3 lit. b u.p.a. Zdaniem Sądu Najwyższego rozpoznającego sprawę leżącą u podstaw pytania prawnego, $\mathrm{z}$ „treści uzasadnienia wyroku Trybunału Konstytucyjnego nie wynika wniosek o utracie mocy art. 79 ust. 1 pkt 3 lit. b ustawy o prawie autorskim i prawach pokrewnych w zakresie możliwości żądania przez autora, którego prawa majątkowe zostały naruszone, odszkodowania w wysokości dwukrotności należnego mu wynagrodzenia [...] Nadawanie temu przepisowi niekiedy w judykaturze i literaturze innej treści normatywnej, niż to wynika wprost z jego brzmienia nie jest dopuszczalne. Kontrola zachowania przez ustawodawcę standardów konstytucyjnych przysługuje bowiem Trybunałowi Konstytucyjnemu” (pytanie prawne, s. 20-21). Niemniej, „wobec przedstawionych rozbieżności konieczne wydaje się ponowne dokonanie kontroli konstytucyjnej normy art. 79 ust. 1 pkt 3 lit. b ustawy o prawie autorskim i prawach pokrewnych (w dalszym zakresie), gdyż w orzecznictwie i doktrynie wskazywane są różne rozwiązania istniejącej niepewności prawnej, to jest wystąpienie do Trybunału Konstytucyjnego, uznanie nieobowiązywania normy 
art. 79 ust. 1 pkt 3 lit. b ustawy o prawie autorskim i prawach pokrewnych w drodze kontroli rozproszonej, uznanie, że istnieją podstawy do przyjęcia zarzutu nadużycia prawa autorskiego" (pytanie prawne, s. 21).

Zdaniem Sądu Najwyższego, „pomimo że przepis art. 79 ust. 1 pkt 3 lit. b ustawy o prawie autorskim i prawach pokrewnych określa roszczenie uprawnionego jako odszkodowanie (instrument służący naprawieniu wyrządzonej szkody majątkowej), to w istocie przewiduje on swoistą karę cywilną, gdyż pozostaje w oderwaniu od wysokości i charakteru poniesionej przez uprawnionego szkody, a również od winy sprawcy deliktu i jej stopnia. Niekiedy przyjmuje się nawet, że roszczenie to jest niezależne od wystąpienia szkody, a istotny jest tylko fakt naruszenia majątkowych prawa autorskich (por. wyrok SN z 8 marca 2012 r., V CSK 102/11, LEX nr 1213427). Wskazać zatem trzeba, że wprawdzie na gruncie kodeksu cywilnego znane są przypadki odpowiedzialności deliktowej na zasadzie ryzyka (np. art. 433, art. 435 k.c. [Kodeksu cywilnego - dopisek J.B.]), ale ustawodawca przewidział wówczas pewne przesłanki egzoneracyjne, których na gruncie kwestionowanego przepisu brak [...] Kwestionowany przepis przewiduje natomiast odpowiedzialność sprawcy, którą można określić jako absolutną, gdyż uzależnioną jedynie od bezprawności zachowania" (pytanie prawne, s. 22).

Sąd Najwyższy uzasadnia, że „biorąc pod uwagę zarówno szeroki wachlarz roszczeń przewidzianych $\mathrm{w}$ art. 79 ustawy o prawie autorskim i prawach pokrewnych dla uprawnionego, którego prawa autorskie lub prawa pokrewne zostały naruszone, jak również brak konieczności udowodnienia przez uprawnionego zarówno charakteru jak i wysokości poniesionej przez niego szkody, obecne rozwiązanie, przewidujące obowiązek zapłaty sumy pieniężnej w wysokości dwukrotności stosownego wynagrodzenia, w dalszym ciągu stanowi nadmierną ingerencję w prawa majątkowe użytkowników praw autorskich, zaburzając równowagę między nimi a uprawnionymi (twórcami bądź producentami). Narusza to konstytucyjną zasadę najłagodniejszego środka i w dalszym ciągu zbyt głęboko wkracza w relacje horyzontalne między podmiotami toczącymi spór o prawa majątkowe" (pytanie prawne, s. 23).

Sąd pytający podkreśla, że „uprawnionego z tytułu naruszenia majątkowych praw autorskich reprezentuje najczęściej (jak w rozpoznawanej sprawie) wyspecjalizowany podmiot, to jest organizacja zbiorowego zarządzania prawami autorskimi. Podmiot ten zapewnia ochronę majątkowych praw autorskich i ułatwia dochodzenie roszczeń od sprawcy deliktu naruszającego takie prawa, m.in. w aspekcie identyfikacji podmiotów naruszających majątkowe prawa autorskie, organizacji i przeprowadzenia postępowania sądowego. Ponadto, materiał dowodowy zebrany w rozpoznawanej sprawie wskazuje, że organizacje zbiorowego zarządzania ustalają stawki opłat licencyjnych (stanowiących następnie podstawę określenia wysokości odszkodowania) w dość arbitralny i trudny do negocjowania sposób, na co wskazuje np. ustalenie tej stawki na poziomie 2,8\%, pomimo stanowiska Komisji Prawa Autorskiego, że powinna ona wynosić 1,6\%, 
a od 1 lipca 2009 r. do chwili obecnej - stawki odpowiadającej 2,2\% wpływów. $\mathrm{Na}$ ten aspekt, świadczący o silnej pozycji organizacji zbiorowego zarządzania majątkowymi prawami autorskimi, zwrócił uwagę Sąd Najwyższy w powołanym już wyroku z dnia 10 listopada 2017 r. (V CSK 41/14) [...] Ustawodawca w art. 79 przewidział bardzo szeroki katalog środków, z jakich może skorzystać osoba, której autorskie prawa majątkowe naruszono, to jest możliwość żądania przez uprawnionego zaniechania naruszenia praw, usunięcia skutków naruszenia, naprawienia wyrządzonej szkody, wydania uzyskanych korzyści, ogłoszenia w prasie. Środki te nie są alternatywne względem siebie (z wyjątkiem formuły roszczenia odszkodowawczego) i mogą być stosowane kumulatywnie" (pytanie prawne, s. 24). W art. 79 ust. 1 pkt 4 u.p.a. przewidziano obowiązek wydania uzyskanych przez sprawcę deliktu korzyści jako odrębne roszczenie. „Uwzględnienie tego aspektu w ramach odszkodowania prowadziłoby zatem do podwójnego zaspokojenia uprawnionego. Jeśli chodzi o krzywdę, jaka mogła powstać po stronie uprawnionego, to nie powinna ona zostać usunięta czy złagodzona w ramach odszkodowania, ale w ramach np. żądania usunięcia skutków naruszenia, przez dokonanie stosownych ogłoszeń bądź też przez zapłatę zadośćuczynienia. Dodatkowo uprawnionemu przysługują jeszcze odsetki ustawowe za opóźnienie na podstawie i w wysokości przewidzianej w art. 481 k.c." (pytanie prawne, s. 25).

Tak skonstruowany mechanizm odszkodowawczy wyraźnie wykracza poza rzeczywiście poniesioną szkodę, co - z woli ustawodawcy - pozostaje poza kontrolą sądu, gdyż wysokość szkody nie wymaga dowodzenia. Takie działanie ustawodawcy, w ocenie Sądu Najwyższego, „narusza zasadę proporcjonalności, gdyż ustawodawca dla realizacji ochrony praw twórców (producentów) posłużył się zbyt uciążliwym dla korzystających z praw autorskich środkiem prowadzącym do całkowitego oderwania się roszczenia uprawnionego od wielkości poniesionej przez niego szkody. Brak podstaw do uznania, że przepis, który pozwala na uzyskanie przez autora znacznie więcej niż wynosi doznana przez niego szkoda, ma uzasadnienie w wartościach wskazanych w art. 31 ust. 3 Konstytucji” (pytanie prawne, s. 25). Jak zauważa Sąd Najwyższy, rozwiązanie takie nie zostało zastosowane np. „w przypadku ochrony praw o zbliżonym charakterze, to jest praw z własności przemysłowej, gdzie sprawca deliktu zobowiązany jest do naprawienia szkody na zasadach ogólnych albo przez zapłatę sumy pieniężnej w wysokości odpowiadającej opłacie licencyjnej albo innego stosownego wynagrodzenia, które byłyby należne tytułem udzielenia przez uprawnionego zgody na korzystanie z wynalazku (art. 287 ust. 1 ustawy z dnia 30 czerwca 2000 r. - Prawo własności przemysłowej ujedn. tekst: Dz. U. 2017.776. t.j.)" (pytanie prawne, s. 25-26).

W konsekwencji sąd pytający uznaje, że „odszkodowanie w wysokości dwukrotności należnej uprawnionemu opłaty stanowi nieproporcjonalną sankcję, która może prowadzić do naruszenia zasady sprawiedliwości społecznej oraz równej ochrony praw majątkowych, którą gwarantuje Konstytucja. Jest ona także nadmierna w stosunku do celu, jakim jest należyte zabezpieczenie twórców 
przed naruszeniem ich praw majątkowych. Zdaniem Sądu Najwyższego, właściwym rozwiązaniem, zapewniającym wystarczającą ochronę twórcy, mogłoby być przyznanie uprawnionemu ryczałtowego odszkodowania odpowiadającego jednokrotności stosownego wynagrodzenia za korzystanie z utworu, a uzyskanie wyższego odszkodowania powinno być możliwe po wykazaniu przez uprawnionego wysokości szkody" (pytanie prawne, s. 26).

\section{Analiza formalnoprawna}

1. Zgodnie z art. 60 ustawy z dnia 30 listopada 2016 r. o organizacji i trybie postępowania przed Trybunałem Konstytucyjnym (Dz. U. poz. 2072, ze zm.; dalej: ustawa o TK) pytanie prawne Prezes Trybunału kieruje do rozpoznania, jeżeli spełnia wymagania przewidziane $\mathrm{w}$ ustawie, $\mathrm{w}$ przeciwnym razie następuje wezwanie do usunięcia stwierdzonych braków. Na tle tej procedury w piśmiennictwie formułowany jest pogląd o istnieniu „quasi wstępnej kontroli pytań prawnych" (P. Tuleja, Wpływ przesłanki funkcjonalnej na sposób rozpoznania pytania prawnego przez Trybunał Konstytucyjny, „Przegląd Sądowy” 2017, nr 6, s. 17). Niezależnie od tej fazy w orzecznictwie sądu konstytucyjnego przyjmuje się, że rozpoznając merytorycznie sprawę, Trybunał na każdym etapie postępowania powinien badać, czy nie zachodzi któraś z ujemnych przesłanek wydania wyroku, skutkujących obligatoryjnym umorzeniem postępowania (zob. m.in. postanowienia TK z: 18 marca 2009 r., sygn. akt P 13/08; 15 października 2009 r., sygn. akt $P$ 120/08; 6 lipca 2010 r., sygn. akt P 34/09; 29 lutego 2012 r., sygn. akt P 3/10; 26 listopada 2015 r., sygn. akt P 32/13; 5 kwietnia 2017 r., sygn. akt P 17/16; 18 grudnia 2018 r., sygn. akt SK 25/18; 20 lutego 2019 r., sygn. akt SK 30/17; 3 lipca 2019 r., sygn. akt SK 14/18).

Dlatego też przed przystąpieniem do merytorycznej analizy konstytucyjności $\mathrm{w}$ niniejszej sprawie należy poczynić ustalenia o charakterze formalnym co do dopuszczalności kontroli zakwestionowanego przepisu w ramach wyznaczonych przez sąd pytający.

2. Punktem wyjścia dla oceny dopuszczalności i zasadności niniejszego pytania prawnego jest fakt, że wskazany przez sąd pytający przepis prawa autorskiego był już przedmiotem kontroli konstytucyjności Trybunału Konstytucyjnego (wyrok TK z 23 czerwca 2015 r., sygn. akt SK 32/14). Jak już wskazano, przywołane orzeczenie dotyczy art. 79 ust. 1 pkt 3 lit. b u.p.a. w odmiennym zakresie zastosowania niż ten, do którego odnosi się pytanie prawne inicjujące niniejsze postępowanie. Innymi słowy, zakresowy charakter przywołanego wyroku oznacza, że Trybunał Konstytucyjny dokonał wiążącej oceny konstytucyjności jedynie w zakresie, w jakim przepis ten operuje „mechanizmem trzykrotności odszkodowania”. Trybunał Konstytucyjny nie orzekał natomiast w sprawie zgodności z Konstytucją tych przepisów ustawy o prawie autorskim i prawach pokrewnych, które przewidują możliwość żądania przez uprawnionego dwukrotności stosownego wynagrodzenia, gdy naruszyciel nie ponosi winy. Wynika $\mathrm{z}$ tego, 
że przepisy te nadal obowiązują i w dalszym ciągu uprawniony, którego autorskie prawa majątkowe zostały naruszone, może alternatywnie do odszkodowania na zasadach ogólnych dochodzić roszczenia o zapłatę sumy pieniężnej w wysokości odpowiadającej dwukrotności stosownego wynagrodzenia, które w chwili jego dochodzenia byłoby należne tytułem udzielenia przez uprawnionego zgody na korzystanie z utworu. Nie oznacza to jednak, że wielokrotności stosownego wynagrodzenia można domagać się jedynie w przypadku niezawinionego naruszenia autorskich praw majątkowych, zaś w przypadku naruszenia zawinionego jedynie naprawienia szkody na zasadach ogólnych. Mimo powstałej luki w przepisach należy opowiedzieć się za taką ich wykładnią, zgodnie z którą w razie zawinionego naruszenia autorskich praw majątkowych uprawniony może domagać się dwukrotności stosownego wynagrodzenia. W przeciwnym wypadku w lepszej sytuacji znalazłby się uprawniony, którego prawa majątkowe naruszono wskutek działań niezawinionych, niż uprawniony wobec sprawcy, którego naruszycielskie działanie miało charakter zawiniony. Tym samym dwukrotności stosownego wynagrodzenia uprawniony będzie mógł domagać się od sprawcy naruszenia zarówno w przypadku działania zawinionego, jak i niezawinionego (zob. np. wyrok Sądu Apelacyjnego w Łodzi z 18 lutego 2016 r., sygn. akt I ACa 1217/15; wyrok Sądu Apelacyjnego w Krakowie z 17 września 2018 r., sygn. akt I ACa 1641/17, a także wyroki SN z: 7 grudnia 2017 r., sygn. akt V CSK 145/17; 16 lutego 2017 r., sygn. akt I CSK 100/16).

Dopuszczalności zasądzenia dwukrotności wynagrodzenia, które uprawniony mógłby uzyskać, gdyby zawarł umowę o wynagrodzenie za korzystanie z utworu, nie przekreśla pogląd SN wyrażony w wyroku z 10 listopada 2017 r., sygn. akt V CSK 41/14, który z uwagi na okoliczności sprawy opowiedział się za jednokrotnością tego wynagrodzenia. Sąd Najwyższy oparł swoje stanowisko na wypowiedzi Trybunału Sprawiedliwości Unii Europejskiej, który w wyroku z 25 stycznia 2017 r. (sygn. akt C-367/15) przyjął, iż w wyjątkowych wypadkach, ze względu na nadużycie prawa, istnieje możliwość korygowania odszkodowania z tytułu naruszenia praw autorskich (szerzej pkt 1.5 stanowiska).

Nie jest więc w niniejszym przypadku spełniona przesłanka zbędności wydania orzeczenia TK z uwagi na zasadę ne bis in idem (zakaz powtórnego orzekania w odniesieniu do identycznego przedmiotu) ani niedopuszczalności orzekania ze względu na rozbieżności linii orzeczniczej. Niemniej poczynione w sprawie o sygn. akt SK 32/14 uwagi należy mutatis mutandis odnieść do analizowanej sprawy. W kontekście przedstawianych zarzutów warto w szczególności zwrócić uwagę na ustalenia dotyczące możliwości ryczałtowego ukształtowania odszkodowania w sprawie o naruszenie praw autorskich per se. Stanowisko to zachowuje aktualność w niniejszej sprawie.

3. Trybunał Konstytucyjny w swoim orzecznictwie wielokrotnie wyjaśniał warunki dopuszczalności merytorycznego rozpoznania pytania prawnego, tj. konieczność łącznego spełnienia trzech przesłanek: podmiotowej, przedmiotowej 
i funkcjonalnej (zob. szerzej np. postanowienie TK z 11 lutego 2015 r., sygn. akt P 44/13, oraz przywołane tam orzecznictwo). Ustalenia te zachowują aktualność również pod rządami obecnej ustawy o TK, gdyż są one determinowane treścią art. 193 Konstytucji (zob. m.in. postanowienia TK z: 16 maja 2017 r., sygn. akt P 115/15; 14 listopada 2017 r., sygn. akt P 13/17).

Ponadto, jak przewiduje art. 52 ust. 2 pkt 4 ustawy o TK, pytanie prawne powinno zawierać uzasadnienie postawionego zarzutu, $\mathrm{z}$ powołaniem argumentów lub dowodów na jego poparcie. Analogiczne wymaganie formułowały również poprzednio obowiązujące przepisy o postępowaniu przed sądem konstytucyjnym - art. 33 ust. 6 pkt 4 ustawy z dnia 22 lipca 2016 r. o Trybunale Konstytucyjnym (Dz. U. poz. 1157), art. 62 ust. 2 pkt 3 ustawy z dnia 25 czerwca 2015 r. o Trybunale Konstytucyjnym (t.j. Dz. U. 2016, poz. 293) oraz art. 32 ust. 1 pkt 4 ustawy z dnia 1 sierpnia 1997 r. o Trybunale Konstytucyjnym (Dz. U. nr 102, poz. 643, ze zm.). Podsumowując i porządkując dotychczasowy dorobek orzeczniczy, dotyczący warunków właściwego wywiązania się przez podmiot inicjujący kontrolę konstytucyjności prawa $\mathrm{z}$ wymogu uzasadnienia postawionego zarzutu niekonstytucyjności, Trybunał Konstytucyjny stwierdził, że „ponad wszelką wątpliwość nie czyni zadość rozważanej powinności samo przedstawienie przepisu stanowiącego przedmiot kontroli i przepisu będącego wzorcem tej kontroli (nawet wraz z podaniem sposobu rozumienia obu wymienionych przepisów), bez przedstawienia chociażby jednego argumentu wskazującego na niezgodność tych regulacji prawnych - w omawianej sytuacji należy uznać, iż zarzut w ogóle nie został uzasadniony. Co więcej, jak wynika z orzecznictwa Trybunału, nie realizują rozpatrywanego wymagania również uwagi nazbyt ogólne, niejasne czy też czynione jedynie na marginesie innych rozważań (zob. wyrok z 5 czerwca 2014 r., sygn. K 35/11, OTK ZU nr 6/A/2014, poz. 61; postanowienie z 13 stycznia 2015 r., sygn. K 44/13, OTK ZU nr 1/A/2015, poz. 4; postanowienie z 12 maja 2015 r., sygn. K 7/14, OTK ZU nr 5/A/2015, poz. 67; postanowienie z 15 lipca 2015 r., sygn. SK 69/13, OTK ZU nr 7/A/2015, poz. 110; wyrok z 31 lipca 2015 r., sygn. K 41/12, OTK ZU nr 7/A/2015, poz. 102; wyrok z 4 listopada 2015 r., sygn. K 1/14, OTK ZU nr 10/A/2015, poz. 163; postanowienie z 4 listopada 2015 r., sygn. K 9/14, OTK ZU nr 10/A/2015, poz. 170; postanowienie z 4 listopada 2015 r., sygn. P 45/13, OTK ZU nr 10/A/2015, poz. 171; postanowienie z 4 listopada 2015 r., sygn. P 102/15, OTK ZU nr 10/A/2015, poz. 172; postanowienie z 26 kwietnia 2016 r., sygn. K 4/15, OTK ZU A/2016, poz. 19; postanowienie z 1 marca 2017 r., sygn. K 13/14, OTK ZU A/2017, poz. 10; wyrok z 13 grudnia 2017 r., sygn. SK 48/15, OTK ZU A/2018, poz. 2). W takich wypadkach uzasadnienie - jako formalnie wadliwe - należy zakwalifikować jako pozorne, równoznaczne z brakiem uzasadnienia" (postanowienie TK z 9 kwietnia 2019 r., sygn. akt K 17/17).

Konieczność uzasadnienia zarzutu sformułowanego we wniosku związana jest $\mathrm{z}$ domniemaniem konstytucyjności norm prawnych oraz z zasadą skargo- 
wości. Zgodnie z wypowiedziami Trybunału Konstytucyjnego: „Kontrola konstytucyjności ustaw przebiega w oparciu o domniemanie, że badane normy są zgodne z konstytucją. Ciężar dowodu spoczywa na podmiocie kwestionującym zgodność ustawy z konstytucją i dopóki nie powoła on konkretnych i przekonywających argumentów prawnych na rzecz swojej tezy, dopóty Trybunał Konstytucyjny uznawać będzie kontrolowane przepisy za konstytucyjne. W przeciwnym razie naruszeniu uległaby zasada kontradyktoryjności postępowania przed Trybunałem Konstytucyjnym, a Trybunał przekształciłby się w organ orzekający z inicjatywy własnej” (zob. np. orzeczenia TK z: 26 kwietnia 1995 r., sygn. akt K 11/94; 31 stycznia 1996 r., sygn. akt K 9/95; wyrok TK z 27 czerwca 2008 r., sygn. akt K 51/07).

Jeżeli brakuje uzasadnienia zarzutu naruszenia określonego wzorca kontroli, mimo że został on podniesiony w petitum wniosku, Trybunał powinien w stosownym zakresie umorzyć postępowanie. Dopuszczenie do merytorycznego rozpatrzenia sprawy oznaczałoby bowiem przerzucenie ciężaru dowodu na sąd konstytucyjny, co z kolei pozostawałoby w sprzeczności z - nawet szeroko rozumianą - zasadą skargowości, na której oparte jest postępowanie przed Trybunałem Konstytucyjnym. Jak wskazał Trybunał: „Zarzut niezgodności przepisu stanowiącego przedmiot zaskarżenia z Konstytucją, ratyfikowaną umową międzynarodową lub ustawą powinien być poparty przytoczeniem argumentów podważających domniemanie konstytucyjności przepisu. Pytanie prawne, w którym przedstawiający je sąd ograniczyłby się do wyrażenia przekonania o niezgodności kwestionowanego przepisu z Konstytucją, a tym bardziej tylko ogólnie powołał się na istniejące w tej kwestii wątpliwości, nie mogłoby być rozpoznane przez Trybunał Konstytucyjny” (wyrok TK z 8 września 2005 r., sygn. akt P 17/04).

4. Oceniając in casu wywiązanie się przez sąd pytający z wymogu uzasadnienia postawionego zarzutu niekonstytucyjności, Sejm przyjmuje za ugruntowanym poglądem Trybunału Konstytucyjnego, że nie czyni zadość rozważanej powinności samo przedstawienie przepisu stanowiącego przedmiot kontroli i przepisu będącego wzorcem tej kontroli (nawet wraz z podaniem sposobu rozumienia obu wymienionych przepisów), bez przedstawienia chociażby jednego argumentu wskazującego na niezgodność tych regulacji prawnych - w takich okolicznościach należy uznać, iż zarzut w ogóle nie został uzasadniony.

Taka sytuacja ma miejsce w odniesieniu do art. 64 ust. 2 Konstytucji wskazanego przez sąd pytający w charakterze związkowego wzorca kontroli. Sąd Najwyższy zwraca uwagę na to, że mechanizm odszkodowawczy w postaci podwójnego wynagrodzenia, gdy korzystanie z praw jest nielegalne, w sposób szczególny uprzywilejowuje uprawnionych z praw autorskich w stosunku do podmiotów uprawnionych $z$ tytułu innych praw o zbliżonym charakterze, jak np. własności przemysłowej, ,gdzie sprawca deliktu zobowiązany jest do naprawienia szkody na zasadach ogólnych albo przez zapłatę sumy pieniężnej w wysokości odpowiadającej opłacie licencyjnej albo innego stosownego wynagrodzenia, które byłyby 
należne tytułem udzielenia przez uprawnionego zgody na korzystanie z wynalazku" (pytanie prawne, s. 26). Ponadto w zakwestionowanej regulacji Sąd Najwyższy upatruje naruszenia konstytucyjnego prawa do równej ochrony prawa własności przez zaburzenie równowagi między użytkownikami praw autorskich a uprawnionymi (twórcami bądź producentami), z uwagi na zbyt głęboką ingerencję $\mathrm{w}$ relacje horyzontalne między podmiotami toczącymi spór o prawa majątkowe, faworyzując jedną z nich, która oprócz roszczenia o zapłatę sumy pieniężnej stanowiącej dwukrotność stosownego wynagrodzenia dysponuje bardzo szerokim katalogiem środków ochrony autorskich praw majątkowych (zob. pytanie prawne, s. 23-24).

Odnosząc się do dopuszczalności tak uzasadnionego zarzutu naruszenia zasady równej ochrony własności, należy wskazać na powoływany wyrok Trybunału Konstytucyjnego o sygn. akt SK 32/14, w którym TK podkreślił, że kontrola prawa do równej ochrony w zakresie własności i innych praw majątkowych może być znacznie ograniczona lub wykluczona. Wyjaśnia on że, „Prima facie ocena tego zarzutu, z punktu widzenia równej ochrony, możliwa jest na dwa sposoby: a) porównując sytuację prawną podmiotu autorskich praw majątkowych i podmiotu prawa te naruszającego b) porównując sytuację prawną podmiotu naruszającego autorskie prawa majątkowe z sytuacją podmiotów naruszających inne prawa, np. własność lub prawa rzeczowe”. Pierwszy sposób, zdaniem TK, jest wykluczony. Poszanowanie zasady równości w kontekście zróżnicowania praw majątkowych polega bowiem na zakazie różnicowania zakresu ochrony z uwagi na podmiot, któremu określone prawo majątkowe przysługuje. Chodzi więc o nakaz równego traktowania osób, którym przysługuje to samo prawo majątkowe. Z kolei dopuszczając drugi sposób oceny, Trybunał wymaga szczegółowej analizy zarówno podobieństw, jak i różnic autorskich praw majątkowych oraz innych praw, które sąd pytający uważa za podobne, a także stopnia ich ochrony. Takich rozważań pytanie prawne nie zawiera. Sąd Najwyższy nie wyjaśnił, na czym polega naruszenie wskazanego wzorca kontroli, nie przeprowadził analizy podobieństw i różnic autorskich praw majątkowych. Samo sformułowanie tezy o jego naruszeniu nie jest równoznaczne $\mathrm{z}$ wykazaniem niekonstytucyjności. Tym samym sąd pytający nie uzasadnił w sposób odpowiedni podnoszonych w tym zakresie zarzutów.

Biorąc powyższe pod uwagę, należy stwierdzić, że sąd pytający nie zawarł w pytaniu prawnym argumentów dowodzących, że ustawodawca doprowadził do nierównego potraktowania określonej klasy podmiotów. Tym samym sąd pytający nie zrealizował obowiązku uzasadnienia zarzutu wynikającego z art. 52 ust. 2 pkt 4 ustawy o TK, co zdaniem Sejmu uniemożliwia jego rozpoznanie w tym zakresie. Z tego względu Sejm wnosi o umorzenie postępowania na podstawie art. 59 ust. 1 pkt 2 ustawy o Trybunałem Konstytucyjnym w zakresie badania zgodności zakwestionowanej regulacji z art. 64 ust. 2 Konstytucji ze względu na niedopuszczalność wydania wyroku. 


\section{Wzorce kontroli}

1. Sąd pytający powołuje w charakterze wzorca art. 64 ust. 1 Konstytucji, który stanowi, iż „Każdy ma prawo do własności, innych praw majątkowych oraz prawo dziedziczenia”.

W orzecznictwie Trybunału Konstytucyjnego na tle art. 64 Konstytucji ugruntowany jest pogląd, że „na ustawodawcy pozytywnym spoczywa nie tylko obowiązek pozytywny stanowienia przepisów i procedur udzielających ochrony prawnej prawom majątkowym, ale także obowiązek negatywny powstrzymania się od przyjmowania regulacji, które owo prawo mogłyby pozbawiać ochrony prawnej lub też ochronę tę ograniczać” (zob. wyroki TK z: 13 kwietnia 1999 r., sygn. akt K 36/98; 29 czerwca 2004 r., sygn. akt P 20/02; 21 grudnia 2005 r., sygn. akt SK 10/05, czy też 20 kwietnia 2009 r., sygn. akt SK 55/08). Ochrona zapewniana własności i innym majątkowym prawom podmiotowym, zgodnie z art. 64 ust. 1 Konstytucji, musi być realna. Kryterium weryfikacji tej cechy jest skuteczność realizacji określonego prawa podmiotowego w konkretnym otoczeniu systemowym, w którym ono funkcjonuje (zob. orzeczenia powołane wyżej oraz wyroki TK z: 25 lutego 1999 r., sygn. akt K 23/98; 12 stycznia 2000 r., sygn. akt P 11/98; 19 grudnia 2002 r., sygn. akt K 33/02, oraz 20 stycznia 2004 r., sygn. akt SK 26/03). Z drugiej strony Trybunał Konstytucyjny podkreśla, że ochrona własności i innych praw majątkowych nie ma charakteru absolutnego, a jej ograniczenia są dopuszczalne z zachowaniem warunków przewidzianych w art. 31 ust. 3 oraz art. 64 ust. 2 i ust. 3 Konstytucji, tj. na podstawie ustawy i z poszanowaniem zasad równości oraz proporcjonalności.

W świetle orzecznictwa Trybunału Konstytucyjnego sprzeczne ze standardem konstytucyjnym są w szczególności rozwiązania normatywne, które tworzą pozorne i nieefektywne mechanizmy ochrony praw podmiotowych (zob. wyrok TK z 1 września 2006 r., sygn. akt SK 14/05). Ochrona zapewniana majątkowym prawom podmiotowym musi być ponadto realna. Punktem odniesienia (kryterium weryfikacji tej cechy) jest skuteczność realizacji określonego prawa podmiotowego w konkretnym otoczeniu systemowym, w którym ono funkcjonuje (zob. orzeczenia powołane wyżej oraz wyroki TK z: 25 lutego 1999 r., sygn. akt K 23/98; 12 stycznia 2000 r., sygn. akt P 11/98; 19 grudnia 2002 r., sygn. akt K 33/02; 20 stycznia 2004 r., sygn. akt SK 26/03). Sąd konstytucyjny wyraził też pogląd, że konstytucyjna ochrona praw majątkowych powinna polegać nie tylko na eliminowaniu działań faktycznych, prowadzących do uniemożliwienia uprawnionemu korzystania z przysługującego prawa, ale także na takim ukształtowaniu unormowań pozytywnych dotyczących treści danego prawa, które w znacznym stopniu ograniczają niebezpieczeństwo jednostronnego zniweczenia ekonomicznej istoty danego prawa, związanej z zachowaniem jego realnej wartości, zwłaszcza w sytuacji zaistnienia zdarzeń obiektywnych, na przykład związanych z głębokimi przeobrażeniami ustroju ekonomicznego państwa (wyrok TK z 3 października 2000 r., sygn. akt K 33/99). 
2. Wzorcem kontroli o charakterze związkowym jest art. 31 ust. 3 Konstytucji, który stanowi, że „Ograniczenia w zakresie korzystania z konstytucyjnych wolności i praw mogą być ustanawiane tylko w ustawie i tylko wtedy, gdy są konieczne w demokratycznym państwie dla jego bezpieczeństwa lub porządku publicznego, bądź dla ochrony środowiska, zdrowia i moralności publicznej, albo wolności i praw innych osób. Ograniczenia te nie mogą naruszać istoty wolności i praw”. Przepis ten jest źródłem normatywnym zasady proporcjonalności (art. 31 ust. 3 zdanie pierwsze Konstytucji), zakazu naruszania istoty prawa i wolności (art. 31 ust. 3 zdanie drugie Konstytucji) oraz zasady wyłączności ustawy (art. 31 ust. 3 zdanie pierwsze Konstytucji).

Analiza orzecznictwa Trybunału Konstytucyjnego prowadzi do wniosku, że zasada proporcjonalności ustala dopuszczalny zakres ograniczeń korzystania z konstytucyjnych wolności i praw. Wymaga od sądu konstytucyjnego odpowiedzi na następujące pytania: czy zaskarżona regulacja ustawowa jest w stanie doprowadzić do zamierzonych przez nią skutków (zasada przydatności), czy regulacja ta jest niezbędna dla ochrony interesu publicznego, z którym jest powiązana (zasada konieczności), a ponadto czy jej efekty pozostają w proporcji do ciężarów nakładanych przez nią na obywatela (zasada proporcjonalności w ścisłym znaczeniu; zob. wyroki TK z: 11 kwietnia 2006 r., sygn. akt SK 57/04; 11 kwietnia 2000 r., sygn. akt K 15/98). Przesłanka proporcjonalności w znaczeniu ścisłym, niezbędna dla uznania zasadności wprowadzenia ograniczenia konstytucyjnych wolności lub praw, oznacza zatem dla ustawodawcy obowiązek wyboru najmniej dolegliwego środka.

Zawarty w art. 31 ust. 3 zdanie drugie Konstytucji zakaz naruszania istoty wolności i praw opiera się na założeniu, że w ramach każdego konkretnego prawa lub wolności można wyodrębnić pewne elementy podstawowe, bez których takie prawo czy wolność w ogóle nie będą mogły istnieć, oraz pewne elementy dodatkowe, które mogą być przez ustawodawcę zwykłego ujmowane i modyfikowane w różny sposób bez zniszczenia tożsamości danego prawa czy wolności (orzeczenie TK z 26 kwietnia 1995 r., sygn. akt K 11/95, oraz wyroki TK z: 12 stycznia 2000 r., sygn. akt P 11/98; 20 października 2010 r., sygn. akt P 37/09).

W wyroku z 12 stycznia 1999 r. (sygn. akt P 2/98) Trybunał Konstytucyjny wyraził nadal aktualny pogląd, że „Interpretacja zakazu naruszania istoty prawa lub wolności nie powinna sprowadzać się jedynie do płaszczyzny negatywnej, akcentującej odpowiednie miarkowanie dokonywanych ograniczeń. Należy w nim widzieć również stronę pozytywną, związaną z dążeniem do wskazania, choćby przykładowo, pewnego nienaruszalnego rdzenia danego prawa lub wolności, który pozostawać winien wolny od ingerencji prawodawcy nawet w sytuacji, gdy działa on w celu ochrony wartości wskazanych w art. 31 ust. 3 zdanie pierwsze Konstytucji. Wskazanie istoty prawa lub wolności powinno uwzględniać przy tym kontekst sytuacji, w której dochodzi do ograniczenia danego uprawnienia”.

Przepis art. 31 ust. 3 Konstytucji wyraża zasadę wyłączności regulacji ustawowej. Pełni ona funkcję gwarancyjną wobec praw i wolności człowieka, za- 
pewniając ochronę jednostki przed nadmierną ingerencją ze strony państwa (zob. K. Wojtyczek, Granice ingerencji ustawodawczej w sfere praw człowieka w Konstytucji RP, Kraków 1999, s. 110). Zasada wyłączności nie polega jedynie na zachowaniu formy ustawowej dla ograniczania wolności. Trybunał Konstytucyjny rozwija jej treść, dodając, że „Skoro ograniczenia mogą być ustanawiane «tylko» w ustawie, to kryje się w tym nakaz kompletności unormowania ustawowego, które musi samodzielnie określać wszystkie podstawowe elementy ograniczenia danego prawa i wolności, tak aby już na podstawie lektury przepisów ustawy można było wyznaczyć kompletny zarys (kontur) tego ograniczenia. Niedopuszczalne jest natomiast przyjmowanie w ustawie uregulowań blankietowych" (wyrok TK z 12 stycznia 2000 r., sygn. akt P 11/98; stanowisko to zostało następnie powtórzone m.in. w wyroku TK z 5 lutego 2008 r., sygn. akt K 34/06). Jednocześnie sąd konstytucyjny wskazał, że: „Wymaganie umieszczenia bezpośrednio w tekście ustawy wszystkich zasadniczych elementów regulacji prawnej musi być stosowane ze szczególnym rygoryzmem, gdy regulacja ta dotyczy władczych form działania organów administracji publicznej wobec obywateli” (wyrok TK z 25 maja 1998 r., sygn. akt U 19/97).

3. Sąd pytający przywołuje w charakterze wzorca kontroli art. 2 Konstytucji, wskazując na naruszenie zasady sprawiedliwości społecznej. Zgodnie z nim „Rzeczpospolita Polska jest demokratycznym państwem prawnym, urzeczywistniającym zasady sprawiedliwości społecznej”. Zasada demokratycznego państwa prawnego ma charakter klauzuli generalnej o wielopłaszczyznowej treści. W ujęciu art. 2 Konstytucji sprawiedliwość społeczna jest celem, który ma urzeczywistniać demokratyczne państwo prawne. Nie jest bowiem demokratycznym państwem prawnym państwo, które nie realizuje idei sprawiedliwości, przynajmniej pojmowanej jako dążenie do zachowania równowagi w stosunkach społecznych i powstrzymywanie się od kreowania nieusprawiedliwionych, niepopartych obiektywnymi wymogami i kryteriami przywilejów dla wybranych grup obywateli. Trybunał Konstytucyjny w swoim dotychczasowym orzecznictwie podkreślał, że na treść zasady sprawiedliwości społecznej składa się wiele zagadnień. Do elementów konstytuujących sprawiedliwość społeczną Trybunał zalicza m.in. tworzenie warunków zdrowego i stabilnego rozwoju gospodarczego (zob. P. Tuleja, Komentarz do art. 2 [w:] Konstytucja RP, t. I, Komentarz. Art. 1-86, red. M. Safjan, L. Bosek, Warszawa 2016, s. 242-243, i powołane tam wyroki Trybunału Konstytucyjnego).

\section{Analiza zgodności}

\section{- 1. Uwagi wstępne}

1.1. Zarzuty Sądu Najwyższego dotyczą możliwości żądania przez uprawnionego, którego majątkowe prawa autorskie zostały naruszone, odszkodowania ryczałtowego, przewyższającego wysokość poniesionej szkody (w wysokości dwukrotności stosownego wynagrodzenia). Analogiczny problem analizowany był przez 
TK w przywoływanym już wyroku o sygn. akt SK 32/14. Nieuniknione jest zatem odwoływanie się do powyższego orzeczenia ze względu na adekwatność i aktualność poczynionych wówczas uwag. Poniższa ocena w głównej mierze nawiązuje do zawartych tam tez.

1.2. Przed przystąpieniem do analizy merytorycznej przedstawionych w pytaniu prawnym zarzutów, celowe jest przedstawienie kontekstu normatywnego kwestionowanej regulacji oraz jej istoty.

Ochrona autorskich praw majątkowych jest ukształtowana na podstawie szczególnych przepisów określających podstawy roszczeń, których można dochodzić w sytuacji naruszenia prawa. Jak wskazuje się w literaturze przedmio$\mathrm{tu}$, naruszeniem autorskich praw majątkowych jest takie działanie, które można kwalifikować jako wkroczenie w zakres cudzego prawa majątkowego. Korzystanie z elementów dzieła spełniających przesłankę twórczości jest naruszeniem monopolu eksploatacyjnego odnoszącego się do danego utworu (zob. J. Barta, R. Markiewicz, Prawo autorskie i prawa pokrewne, Warszawa 2011, s. 483, zob. także np. wyroki Sądu Apelacyjnego w Warszawie z: 23 grudnia 2014 r., sygn. akt I ACa 703/14; 21 września 2018 r., sygn. akt I ACa 218/18). Faktyczna eksploatacja cudzego utworu bez zezwolenia jest naruszeniem prawa autorskiego, a na ustalenie, iż doszło do naruszenia tego prawa, nie ma wpływu charakter czy też poziom artystyczny lub naukowy wykorzystywanego dzieła bądź wielkość wkładu twórczego. Bez znaczenia jest również to, że wkroczenie w cudze prawa autorskie było dokonywane bez zamiaru lub świadomości naruszenia. Autorskie prawa majątkowe są zatem chronione w sposób bezwzględny (zgodnie $z$ charakterem prawnym tych praw) i obiektywny. Do zakwalifikowania działań jako naruszających prawa uprawnionych podmiotów wystarczające jest wykazanie bezprawności.

Podstawową rolę kompensacyjną w prawie autorskim odgrywają roszczenia odszkodowawcze. Obecny katalog roszczeń z tytułu naruszenia autorskich praw majątkowych jest wynikiem m.in. implementacji przepisów dyrektywy 2004/48/WE Parlamentu Europejskiego i Rady z dnia 29 kwietnia 2004 r. w sprawie egzekwowania praw własności intelektualnej (Dz. Urz. UE L 157/45 z 2004 r.; dalej: dyrektywa 2004/48/WE), w której przewidziano szczególną regulację środków prawnych oraz kwestii procesowych w odniesieniu do naruszeń praw własności intelektualnej. Implementacja dyrektywy 2004/48/WE miała doprowadzić do ustalenia zbliżonego poziomu ochrony praw własności intelektualnej w państwach członkowskich (zob. A. Tischner, Komentarz do zmiany art. 79 ustawy o prawie autorskim i prawach pokrewnych wprowadzonej przez Dz. U. $z 2007$ r. Nr 99 poz. 662 [w:] T. Targosz, A. Tischner, Komentarz do ustawy z dnia 9 maja 2007 r. o zmianie ustawy o prawie autorskim $i$ prawach pokrewnych oraz niektórych innych ustaw, 2008, LEX nr 34672, teza 1; A. Drzewiecki [w:] Ustawa o prawie autorskim i prawach pokrewnych. Komentarz, red. E. Ferenc-Szydełko, 2014, Legalis, s. 554). Istotą dyrektywy 2004/48/WE jest zatem usunięcie różnic 
między poszczególnymi ustawodawstwami w zakresie środków służących realizacji ochrony praw własności intelektualnej. Zróżnicowanie prowadzi bowiem do „sytuacji, w której ochrona w niektórych państwach jest mniej intensywna, co niekorzystnie wpływa na konkurencję i stanowi zachętę do podejmowania działalności w państwach o niższym poziomie ochrony (mniej rygorystycznym systemie), obliczoną na wykorzystywanie tych różnic i prowadzącą do naruszenia zasad uczciwej konkurencji” (J. Błeszyński, Opinia prawna dot. nowelizacji ustawy o prawie autorskim i prawach pokrewnych oraz o zmianie innych ustaw, druk sejmowy nr 1241/V kad., opinia sporządzona 13 lutego 2007 r., niepubl.).

Dyrektywa 2004/48/WE, oprócz zagadnień dotyczących prawa do informacji, gromadzenia i przedstawiania dowodów oraz środków tymczasowych i zabezpieczających, reguluje także problematykę odszkodowawczą. Uchwalenie dyrektywy wymusiło na ustawodawcy nowelizację prawa krajowego. W wyniku zmian wprowadzonych m.in. ustawą z dnia 9 maja 2007 r. o zmianie ustawy o prawie autorskim i prawach pokrewnych oraz niektórych innych ustaw (Dz. U. nr 99, poz. 662; dalej: nowelizacja z 2007 r.), która weszła w życie 20 czerwca 2007 r., katalog roszczeń przysługujących z tytułu naruszenia praw własności intelektualnej został poszerzony o roszczenie o usunięcie skutków naruszenia, a tzw. roszczenie publikacyjne uległo modyfikacji.

1.3. Roszczenia wymienione w art. 79 u.p.a. mają na celu naprawienie szkody i przywrócenie stanu sprzed naruszenia. Obok roszczeń negatoryjnych zmierzają do usunięcia stanu niezgodnego z prawem, zapewniając uprawnionemu możliwość rekompensaty poniesionych strat i utraconych korzyści. Wybór roszczenia przysługuje uprawnionemu (zob. M. Jankowska, Komentarz do art. 79, teza 1 [w:] Ustawa o prawie autorskim i prawach pokrewnych. Komentarz, red. P. Slęzak, 2017, Legalis). Mają one charakter samoistny i pozostają ze sobą w zbiegu, zwłaszcza w przypadku naruszeń ciągłych, polegających na eksploatacji cudzego prawa (zob. P. Podrecki, Komentarz do art. 79, teza 1 [w:] M. Bukowski i in., Prawo autorskie i prawa pokrewne. Komentarz, 2015, LEX nr 466622; J. Barta, R. Markiewicz, Prawo autorskie i prawa pokrewne, op. cit., s. 502).

Podstawowym środkiem cywilnoprawnej ochrony przysługującym uprawnionemu $z$ tytułu naruszenia autorskich praw majątkowych jest, niezależne od winy naruszyciela, roszczenie o zaniechanie (art. 79 ust. 1 pkt 1 u.p.a.). Stanowi ono typowy środek ochrony praw bezwzględnych o charakterze obiektywnym. Żądanie zaniechania naruszeń może oznaczać zarówno ich zaprzestanie, jak i niepodejmowanie. Celem takiego roszczenia jest umożliwienie uprawnionemu prawidłowego korzystania z przysługującego mu monopolu prawnego. Roszczenie o usunięcie skutków naruszenia należy również do tradycyjnych środków tzw. ochrony negatoryjnej praw własności intelektualnej. Mimo że roszczenie to zostało wprowadzone do katalogu środków ochrony autorskich praw majątkowych nowelizacją z 2007 r., część doktryny dopuszczała występowanie z tym roszczeniem również wcześniej (zob. A. Tischner, Komentarz, op. cit., tezy 4-5). 
Do katalogu środków ochrony zostało również wprowadzone roszczenie o usunięcie skutków naruszenia (art. 79 ust. 1 pkt 2 u.p.a.). Podobnie jak w przypadku roszenia o zaniechanie, $\mathrm{w}$ literaturze dopuszczano występowanie $\mathrm{z}$ tym roszczeniem jeszcze przed nowelizacją z 2007 r. (zob. J. Barta, R. Markiewicz, Prawo autorskie i prawa pokrewne, op. cit., s. 606; E. Ferenc-Szydełko [w:] Ustawa o prawie autorskim i prawach pokrewnych. Komentarz, red. E. Ferenc-Szydełko, Warszawa 2014, s. 566). Roszczenie o usunięcie skutków naruszenia można zaliczyć do kategorii roszczeń o charakterze restytucyjnym, których realizacja następuje w drodze przywrócenia stanu poprzedniego (restitutio in integrum). Nowością wynikającą z konieczności dostosowania prawa polskiego do wymogów dyrektywy 2004/48/WE jest możliwość zastępczej realizacji roszczeń o zaniechanie naruszeń i usunięcie ich skutków przez zapłatę odpowiedniej sumy pieniężnej (art. 79 ust. 3 u.p.a.). Środek ten sąd stosuje na wniosek naruszyciela i za zgodą uprawnionego, wówczas gdy naruszenie jest niezawinione, a zaniechanie naruszenia lub usunięcie skutków naruszenia byłoby dla osoby naruszającej niewspółmiernie dotkliwe. Środek ten ma łagodzić dolegliwość związaną z realizacją roszczeń negatoryjnych. Wprowadza możliwość majątkowej kompensacji działań, do których naruszyciel byłby zobowiązany w ramach realizacji roszczeń o zaniechanie i usunięcie skutków. Zastosowanie tego środka zależy od decyzji sądu, który wyważa interesy obu stron (zob. A. Tischner, Komentarz, op. cit., tezy 4-5).

Implementacja dyrektywy 2004/48/WE spowodowała także istotne zmiany $\mathrm{w}$ regulacji pozostałych roszczeń majątkowych $\mathrm{z}$ tytułu naruszenia autorskich praw majątkowych, przede wszystkim roszczeń odszkodowawczych, które są jednymi z zasadniczych środków ochrony w prawie autorskim. W ustawie o prawie autorskim i prawach pokrewnych, po zmianach wprowadzonych nowelizacją z 2007 r., można wskazać kilka postaci roszczeń odszkodowawczych, z którymi może występować uprawniony.

Pierwszy rodzaj roszczenia odszkodowawczego to roszczenie oparte na zasadach ogólnych. Odwołanie do zasad odpowiedzialności stanowi implementację postanowień art. 13 ust. 1 lit. a dyrektywy 2004/48/WE. Zgodnie z art. 79 ust. 1 pkt 3 lit. a u.p.a. naprawienie wyrządzonej szkody może być dochodzone na zasadach odpowiedzialności odszkodowawczej określonych w ustawie z dnia 23 kwietnia 1964 r. - Kodeks cywilny (t.j. 2019, poz. 1145, ze zm.; dalej: Kodeks cywilny lub k.c.). Prowadzi to do wniosku, że zastosowanie znajdują nie tylko zasady odpowiedzialności odszkodowawczej określone w art. 361 k.c., ale także przesłanki odpowiedzialności deliktowej opisane w art. 415 k.c. W literaturze przyjmuje się, że jest to zatem typowe, oparte na winie, cywilnoprawne roszczenie odszkodowawcze (zob. J. Barta, R. Markiewicz, Prawo autorskie i prawa pokrewne, op. cit., s. 494-495; A. Drzewiecki [w:] Ustawa o prawie autorskim, op. cit., s. 573; J. Błeszyński Ochrona majątkowych praw autorskich na drodze cywilnej [w:] System prawa prywatnego, t. 13, Prawo autorskie, red. J. Barta, Warszawa 2017, s. 981). Występuje także stanowisko, zgodnie z którym „odpowiedzialność 
na zasadzie winy w prawie autorskim powodowałaby utratę funkcji zryczałtowanego odszkodowania. Ma ono bowiem poprawiać sytuację poszkodowanego, który mógłby mieć trudności w wykazaniu wysokości swojej szkody lub korzyści uzyskanych przez naruszyciela, powinno zatem stanowić alternatywę dla odszkodowania obliczonego na zasadach ogólnych (lub także roszczenia o wydanie korzyści). Tymczasem polskie prawo autorskie przyznawałoby wysokie zryczałtowane odszkodowanie także wówczas, gdy ze względu na brak winy odmawia odszkodowania zwykłego" (P. Machnikowski, Funkcja prewencyjna roszczeń pieniężnych powstających $w$ razie naruszenia praw własności intelektualnej [w:] Spory o własność intelektualną. Ksiega jubileuszowa dedykowana Profesorom Januszowi Barcie i Ryszardowi Markiewiczowi, red. A. Matlak, S. Stanisławska-Kloc, Warszawa 2013, s. 512). Przy ustalaniu wysokości odszkodowania uwzględnia się zarówno damnum emergens, jak i lucrum cessans. Specyfika ustalania wysokości szkody wynikającej z naruszenia autorskich praw majątkowych wiąże się z tym, że szkody te polegają na utracie spodziewanych korzyści z ekonomicznej eksploatacji dzieła (zob. P. Bogdalski, Środki ochrony autorskich praw majątkowych oraz ich dochodzenie w świetle prawa polskiego, Kraków 2003, s. 94). Zgodnie z orzecznictwem Sądu Najwyższego na podstawie art. 322 ustawy z dnia 17 listopada 1964 r. - Kodeks postępowania cywilnego (t.j. Dz. U. 2019, poz. 1460, ze zm.; dalej: k.p.c.), w przypadku istnienia trudności lub braku możliwości udowodnienia wysokości roszczeń, sąd może zasądzić stosowne wynagrodzenie według swojej oceny opartej na rozważeniu wszystkich okoliczności sprawy (wyroki SN z: 25 marca 2004 r., sygn. akt l CK 90/03; 21 lutego 2007 r., sygn. akt I CK 446/06). W praktyce, głównie ze względu na trudności dowodowe w szczególności w zakresie winy oraz rozmiaru szkody, jest ono rzadko wybierane przez uprawnionych (zob. A. Drzewiecki [w:] Ustawa o prawie autorskim, op. cit., s. 574).

Alternatywnie w ustawie o prawie autorskim i prawach pokrewnych przewiduje się model zryczałtowanego odszkodowania (tego rodzaju roszczenia dotyczy pytanie prawne). Zgodnie z art. 79 ust. 1 pkt 3 lit. b u.p.a. szkoda może być naprawiona przez zapłatę sumy pieniężnej w wysokości odpowiadającej wielokrotności stosownego wynagrodzenia (aktualnie jedynie dwukrotności, zob. wyrok TK z 23 czerwca 2015 r., sygn. akt SK 32/14), z chwili jego dochodzenia. Zgodnie $\mathrm{z}$ utrwalonym $\mathrm{w}$ orzecznictwie sądowym poglądem „stosowne wynagrodzenie" w rozumieniu art. 79 ust. 1 u.p.a. to takie wynagrodzenie, jakie otrzymałby podmiot prawa autorskiego (lub praw pokrewnych), gdyby osoba, która naruszyła jego prawa majątkowe, zawarła z nim umowę o korzystanie z utworu w zakresie dokonanego naruszenia w chwili dochodzenia naprawienia szkody. Interpretacja taka została przyjęta m.in. w wyroku SN z 25 marca 2004 r., sygn. akt II CK 90/03 (zob. także: wyrok SN z 29 listopada 2006 r., sygn. akt II CSK 245/06; wyroki sądów apelacyjnych: we Wrocławiu z 23 marca 2008 r., sygn. akt ACa 456/08; w Łodzi z 4 marca 2014 r., sygn. akt 1 Aca 1147/13; w Szczecinie z 29 września 2014 r., sygn. akt 1 Aca 374/14; w Krakowie z 30 grudnia 2014 r., 
sygn. akt 1 Aca 1420/14). Nawiązując do powołanego orzecznictwa, w wyroku o sygn. akt SK 32/14 Trybunał Konstytucyjny wskazał: „Jeszcze przed wejściem w życie nowelizacji prawa autorskiego, która implementowała dyrektywę 2004/48/WE, Sąd Najwyższy przyjął, że wynagrodzeniem stosownym w rozumieniu art. 79 ust. 1 prawa autorskiego jest wynagrodzenie, jakie otrzymywałby autor, gdyby osoba, która naruszyła jego prawa majątkowe, zawarła z nim umowę o korzystanie z utworu w zakresie dokonanego naruszenia. Z kolei w odniesieniu do sposobu ustalania wysokości wynagrodzeń, dochodzonych w zakresie zbiorowego zarządzania przez o.z.z. [organizacja zbiorowego zarządzania prawami autorskimi - dopisek J.B.], w orzecznictwie wskazywano, iż w sytuacji braku tabel wysokość wynagrodzenia powinna być wyznaczana z uwzględnieniem wpływów osiąganych w związku z korzystaniem z utworu jak również z uwzględnieniem charakteru i zakresu korzystania z niego. Postulat ten odpowiadał treści art. 110 u.p.a. W orzecznictwie podnoszono, że należy również brać pod uwagę rynkowe stawki w kraju, a także za granicą, oraz stawki stosowane przez o.z.z. na danym polu eksploatacji”.

Ponadto, zgodnie z art. 79 ust. 1 pkt 4 u.p.a., podmiot, którego autorskie prawa majątkowe zostały naruszone, może dochodzić wydania uzyskanych przez naruszyciela korzyści. Z żądaniem wydania uzyskanych korzyści można wystąpić niezależnie od tego, czy naruszenie było zawinione. W literaturze przedmiotu istnieją rozbieżności odnośnie do natury oraz zakresu tego roszczenia. Wątpliwości wzbudza zwłaszcza relacja tego roszczenia do instytucji bezpodstawnego wzbogacenia (art. 405 k.c.). Według dominującego poglądu przedstawicieli nauki, roszczenie o wydanie korzyści stanowi samodzielną podstawę odpowiedzialności, różną od bezpodstawnego wzbogacenia (tak m.in. J. Barta, R. Markiewicz, Prawo autorskie i prawa pokrewne, op. cit., s. 497; J. Błeszyński, Ochrona majątkowych praw autorskich, op. cit., s. 999-1000; P. Bogdalski, Środki ochrony autorskich praw majątkowych, op. cit., s. 99; A. Drzewiecki [w:] Ustawa o prawie autorskim, op. cit., s. 584). Roszczenie to pozostaje w zbiegu z innymi roszczeniami z tytułu naruszenia, $\mathrm{w}$ tym $\mathrm{z}$ roszczeniem odszkodowawczym (orzeczenie SN z 22 października 1974 r., sygn. akt II CR 406/74). W większości przypadków uprawniony dokona wyboru między roszczeniem odszkodowawczym a roszczeniem o wydanie korzyści. W punktu widzenia postępowania dowodowego mniej problemów jest $\mathrm{z}$ dochodzeniem roszczenia o wydanie korzyści. Udowodnienie winy naruszyciela, a przede wszystkim poniesionej szkody jest problematyczne. Wykazanie i udokumentowanie uzyskanych korzyści oraz ich wielkości - mimo iż także nie należy do najprostszych, przynajmniej co do zasady, jest łatwiejsze. Obok faktu naruszenia stanowi ono bowiem jedyną przesłankę wymagającą udowodnienia (A. Drzewiecki [w:] Ustawa o prawie autorskim, op. cit., s. 593-594).

Podmiot autorskich praw majątkowych, niezależnie od roszczeń o zapłatę na swoją rzecz wielokrotności stosownego wynagrodzenia, może domagać się, przy spełnieniu warunków z art. 79 ust. 2 pkt 2 u.p.a., zasądzenia od naruszyciela 
odpowiedniej sumy pieniężnej na rzecz Funduszu Promocji Twórczości. Ponadto może on wystąpić z żądaniem: jednokrotnego lub wielokrotnego ogłoszenia w prasie oświadczenia odpowiedniej treści i w odpowiedniej formie, lub podania do publicznej wiadomości części albo całości orzeczenia sądu wydanego w rozpatrywanej sprawie, w sposób i w zakresie określonym przez sąd (art. 79 ust. 2 pkt 1 u.p.a.).

Podsumowując, należy stwierdzić, że z przedstawionych ogólnych wywodów dotyczących roszczeń, służących z tytułu naruszenia autorskich praw majątkowych, należy odnotować ich szczególną naturę, która wynika z istoty prawa autorskiego. Ich podstawową cechą jest bezwzględny i obiektywny charakter. Przesłanką odpowiedzialności jest, co do zasady, bezprawność działania naruszyciela, w związku z czym jest to odpowiedzialność uniezależniona od winy. Ratio takiej konstrukcji roszczeń przysługujących w wypadku naruszenia majątkowych praw autorskich jest specyfika przedmiotu ochrony, elementy osobiste polegające na powiązaniu utworu z twórcą oraz jego silna pozycja. Odmienność ujęcia treści majątkowego prawa autorskiego polega przede wszystkim na niematerialnym charakterze przedmiotu o nieograniczonej - czasowo i terytorialnie - zdolności eksploatacyjnej oraz na tym, że „prawo autorskie przesycone jest elementami osobistymi” (J. Błeszyński, Ochrona majątkowych praw autorskich, op. cit., s. 787). W związku z powyższym ujawnia się pierwszorzędna rola roszczeń zawartych w art. 79 ust. 1 pkt 3 lit. b u.p.a. Omawiane roszczenia są postrzegane jako specyficzne roszczenie odszkodowawcze, odbiegające w sposób zasadniczy od klasycznych konstrukcji cywilnoprawnych. Nie mają one swych odpowiedników w Kodeksie cywilnym. Oryginalny charakter tej regulacji przejawia się w kilku elementach: po pierwsze, w odstępstwie od zasady restytucji na rzecz ustawowego ryczałtu odszkodowawczego (dwukrotność wysokości wynagrodzenia), po drugie, w zobiektywizowaniu odpowiedzialności, po trzecie, we wprowadzeniu „elementu represyjnego” w przypadku wykazania winy sprawcy (zob. A. Drzewiecki [w:] Ustawa o prawie autorskim, op. cit., nb. 43).

1.4. Katalog roszczeń związanych $\mathrm{z}$ naruszeniem autorskich praw majątkowych przypisany został podmiotom, które ustawodawca określił w art. 79 u.p.a. jako „uprawnieni”. Jak wskazuje się w doktrynie, wśród „uprawnionych” w rozumieniu tego przepisu znajdują się: twórca lub pierwotny podmiot autorskich praw majątkowych oraz ich następcy prawni. Legitymacja czynna przysługuje ponadto licencjobiorcy wyłącznemu (art. 67 ust. 4 u.p.a.) oraz organizacjom zbiorowego zarządzania prawami autorskimi i prawami pokrewnymi (dalej: organizacja z.z.).

Status organizacji zbiorowego zarządzania prawami autorskimi był już przedmiotem analizy Trybunału w wyroku z 21 listopada 2005 r. (sygn. akt P 10/03). Trybunał wskazał wówczas, że „Nie podając definicji organizacji z.z., ustawa o prawie autorskim określa podstawowe wymogi, które organizacja taka powinna spełniać. Organizacja z.z. jest więc: 1) stowarzyszeniem zarejestrowanym; 
2) zrzeszeniem twórców, artystów wykonawców, producentów lub organizacji radiowych albo telewizyjnych; 3) jej zadaniem statutowym jest zbiorowe zarządzanie, ochrona powierzonych jej praw autorskich lub praw pokrewnych oraz wykonywanie uprawnień wynikających $\mathrm{z}$ ustawy. Członkami organizacji z.z. mogą być jedynie twórcy, artyści wykonawcy, producenci, organizacje radiowe i telewizyjne. Podkreślić należy, że ustawa nie formułuje obowiązku przynależności twórców. Przepis art. 107 ustawy o prawie autorskim stanowi natomiast, że w sytuacji gdy na danym polu eksploatacji działa więcej niż jedna organizacja z.z., a twórca lub artysta wykonawca nie należy do żadnej z nich albo nie ujawnił swojego autorstwa - organizację właściwą wskazuje Komisja Prawa Autorskiego. Statutowym zadaniem organizacji z.z. jest zbiorowe zarządzanie prawami autorskimi lub pokrewnymi, ich ochrona i wykonywanie uprawnień wynikających z prawa autorskiego. Organizacje z.z. kontrolują sposób i zakres korzystania przez użytkowników z praw powierzonych im przez uprawnionych, pobierają należne $\mathrm{z}$ tego tytułu wynagrodzenie i przekazują je reprezentowanym przez siebie podmiotom. Użytkownik nie nabywa praw autorskich czy też innych praw pokrewnych. Otrzymuje jedynie licencję na korzystanie z tych praw".

1.5. W sprawie o sygn. akt SK 32/14 Trybunał Konstytucyjny przedstawił doktrynalną ocenę sposobu implementacji dyrektywy 2004/48/WE, stwierdzając, że ,jakkolwiek zatem art. 2 ust. 1 dyrektywy 2004/48/WE zawiera klauzulę generalną, która umożliwia wprowadzenie ustawodawcy krajowemu regulacji korzystniejszych dla uprawnionego aniżeli wynikające wprost $\mathrm{z}$ tej dyrektywy, to $\mathrm{w}$ doktrynie kwestionuje się zgodność regulacji zawartych $\mathrm{w}$ art. 79 prawa autorskiego z duchem dyrektywy 2004/48/WE oraz kontynentalnymi zasadami odpowiedzialności odszkodowawczej. Innymi słowy - roszczenia oparte na konstrukcji «kary cywilnej» są kwestionowane przez przedstawicieli doktryny jako niedopuszczalne z punktu widzenia celów i założeń dyrektywy". Zanim jeszcze o niezgodności art. 79 ust. 1 pkt 3 lit. b u.p.a. z Konstytucją wypowiedział się Trybunał Konstytucyjny, zarówno w judykaturze, jak i doktrynie rozważano, czy zasadna jest tak surowa odpowiedzialność naruszającego cudze prawa autorskie, która jest niezależna od jego winy, świadomości naruszenia oraz dobrej wiary $\mathrm{w}$ razie korzystania $\mathrm{z}$ utworu, zwłaszcza że równolegle jest dopuszczone dochodzenie odszkodowania na zasadach ogólnych.

Ze względu na powyższe wątpliwości, postanowieniem z 15 maja 2015 r. Sąd Najwyższy zwrócił się do Trybunału Sprawiedliwości Unii Europejskiej (dalej: Trybunał Sprawiedliwości albo TSUE) o wydanie orzeczenia prejudycjalnego, odnośnie do zgodności unormowania wskazanej kwestii w polskim prawie autorskim z art. 13 dyrektywy nr 2004/48/WE. W wyroku z 25 stycznia 2017 r. (sygn. akt C-367/15), Trybunał Sprawiedliwości stwierdził: „Artykuł 13 dyrektywy 2004/48/WE Parlamentu Europejskiego i Rady z dnia 29 kwietnia 2004 r. w sprawie egzekwowania praw własności intelektualnej należy interpretować $\mathrm{w}$ ten sposób, że nie sprzeciwia się on uregulowaniu krajowemu, takiemu jak to 
będące przedmiotem sporu w postępowaniu głównym, zgodnie z którym uprawniony, którego prawo własności intelektualnej zostało naruszone, może zażądać od osoby, która naruszyła to prawo, albo odszkodowania za poniesioną przez niego szkodę, przy uwzględnieniu wszystkich właściwych aspektów danej sprawy, albo, bez wykazywania przez tego uprawnionego rzeczywistej szkody, domagać się zapłaty sumy pieniężnej w wysokości odpowiadającej dwukrotności stosownego wynagrodzenia, które byłoby należne tytułem udzielenia zgody na korzystanie z danego utworu".

Jak następnie wskazał TSUE, powyższej wykładni nie sprzeciwia się fakt, że odszkodowanie obliczone na podstawie dwukrotności stosownej opłaty nie jest proporcjonalne do rzeczywiście poniesionej szkody. Jest to bowiem nieodłączny aspekt każdego odszkodowania ryczałtowego (na wzór tego, które jest przewidziane explicite w art. 13 dyrektywy 2004/48/WE). Co więcej, powyższego nie podważa również to, że celem dyrektywy 2004/48/WE nie jest wprowadzenie obowiązku polegającego na zastosowaniu odszkodowań o charakterze kary. „Z jednej bowiem strony, w przeciwieństwie do tego, co zdaje się uważać sąd odsyłający, fakt, że dyrektywa 2004/48 nie przewiduje obowiązku zastosowania przez państwa członkowskie tak zwanych odszkodowań «o charakterze kary», nie może być interpretowany jako zakaz wprowadzenia tego rodzaju środka. Z drugiej strony, nie orzekając w przedmiocie kwestii, czy wprowadzenie tak zwanych odszkodowań «o charakterze kary» byłoby sprzeczne $\mathrm{z}$ art. 13 dyrektywy 2004/48, nie wydaje się, by mający zastosowanie w postępowaniu głównym przepis przewidywał obowiązek zapłaty tego rodzaju odszkodowań”. Ponadto w ocenie TSUE, „jeżeli chodzi o argument, że strona poszkodowana, skoro mogłaby obliczyć odszkodowanie na podstawie dwukrotności hipotetycznej opłaty licencyjnej, nie musiałaby już wykazywać związku przyczynowego pomiędzy zdarzeniem naruszającym prawo autorskie a poniesioną szkodą, to należy stwierdzić, że argument ten opiera się na zbyt daleko idącej wykładni pojęcia «przyczynowy», zgodnie z którą uprawniony, którego prawo zostało naruszone, musiałby wykazać związek przyczynowy pomiędzy tymże zdarzeniem i nie tylko poniesioną szkodą, lecz również konkretną kwotą, do której ta szkoda się sprowadza. Tego rodzaju wykładnia jest nie do pogodzenia $\mathrm{z}$ samą ideą ustalania ryczałtowego odszkodowania, a zatem z art. 13 ust. 1 akapit drugi lit. b) dyrektywy 2004/48, który zezwala na tego rodzaju odszkodowanie" (wyrok TSUE z 25 stycznia 2017 r., sygn. akt C-367/15).

Wyrok TSUE potwierdza zatem, że każdy uprawniony ma prawo do wyboru modelu ustalania wysokości odszkodowania; może domagać się albo odszkodowania za poniesioną szkodę, albo zapłaty odpowiedniej sumy. W pierwszej sytuacji należy uwzględnić wszystkie właściwe aspekty danej sprawy, co w prawie polskim odpowiada naprawieniu szkody na zasadach ogólnych. W drugim wypadku natomiast odszkodowanie jest ustalane bez wykazywania przez uprawnionego rzeczywistej szkody. Może on domagać się zapłaty sumy pieniężnej w wysokości odpowiadającej dwukrotności stosownego wynagrodzenia. Trybunał 
Sprawiedliwości stwierdza jednoznacznie, że: „art. 13 ust. 1 akapit drugi lit. b) dyrektywy 2004/48 należy zatem interpretować w ten sposób, że nie sprzeciwia się on uregulowaniu krajowemu, takiemu jak art. 79 ust. 1 pkt 3 lit. b pr. aut.”. Podkreśla też, że „zwykła zapłata” opłaty licencyjnej nie zapewnia odszkodowania za całość rzeczywiście poniesionej szkody. „Nie zapewnia bowiem ani zwrotu ewentualnych wydatków związanych z badaniem i identyfikacją możliwych aktów naruszenia, o których mowa w motywie 26 dyrektywy 2004/48, ani zadośćuczynienia za możliwą doznaną krzywdę (zob. w tym ostatnim względzie wyrok z dnia 17 marca 2016 r., Liffers, C-99/15, EU:C:2016:173, pkt 26), ani też zapłaty odsetek za należne kwoty".

Poczynione wyżej uwagi prowadzą do wniosku, że TSUE w wyroku z 25 stycznia 2017 r. (sygn. akt C-367-15) uznał za zgodne z prawem unijnym uregulowanie krajowe umożliwiające uprawnionemu, którego majątkowe prawa autorskie zostały naruszone, żądanie zapłaty sumy pieniężnej w wysokości odpowiadającej dwukrotności stosownego wynagrodzenia, które byłoby należne tytułem udzielenia zgody na korzystanie $\mathrm{z}$ danego utworu. $\mathrm{Z}$ zajętego przez TSUE stanowiska wynika, że postanowienia dyrektywy 2004/48/WE nie sprzeciwiają się krajowe$\mathrm{mu}$ uregulowaniu odszkodowania za nielegalne wykorzystywanie cudzych majątkowych praw autorskich oraz, że art. 79 ust. 1 pkt 3 lit. b u.p.a. odpowiada postanowieniom dyrektywy.

W ocenie TSUE nie można jednak wykluczyć, że w wyjątkowych wypadkach odszkodowanie za szkodę obliczone na podstawie dwukrotności hipotetycznej opłaty licencyjnej mogłoby na tyle „wyraźnie i znacząco” wykraczać poza rzeczywiście poniesioną szkodę, że tego rodzaju żądanie stanowiłoby zakazane w art. 3 ust. 2 dyrektywy 2004/48/WE nadużycie prawa (zob. wyrok TSUE z 25 stycznia 2017 r., sygn. akt C-367-15, teza nr 31).

1.6. Sąd Najwyższy, który zwrócił się z pytaniem prejudycjalnym, wyrokiem z 10 listopada 2017 r. (sygn. akt V CSK 41/14) uznał w związku z tym, że w analizowanej sprawie zachodzi wyjątkowy przypadek wskazany przez TSUE, kiedy odszkodowanie „wyraźnie i znacząco” wykracza poza poniesioną szkodę. Z tego względu w stanie faktycznym zawisłej sprawy za uzasadnione - w ocenie SN należało uznać przyznanie uprawnionemu jednokrotnej opłaty, którą uzyskałby, gdyby z jego prawa korzystano legalnie. Sąd Najwyższy stwierdził, że art. 79 ust. 1 pkt 3 b u.p.a. uprawnia do żądania jednokrotności należnego wynagrodzenia bez konieczności wykazywania szkody, związku przyczynowego i winy sprawcy. Ponadto, jeżeli szkoda uprawnionego jest wyższa, może on żądać od osoby, która te prawa naruszyła, dalszej kwoty na zasadach ogólnych.

Należy jednak zwrócić uwagę na stan faktyczny sprawy rozstrzyganej przez Sąd Najwyższy. Stronami sporu były w niej podmiot reprezentowany przez organizację zbiorowego zarządzania prawami autorskimi oraz stowarzyszenie, które dokonywało reemisji programów telewizyjnych, korzystając z praw autorskich na podstawie umowy zawartej z instytucją zbiorowego zarządzania prawami autor- 
skimi. Bezprawność korzystania z tych praw pojawiła się dopiero w warunkach, gdy organizacja z.z. umowę tę wypowiedziała, proponując zawarcie nowej, ze znacznie wyższą opłatą licencyjną. Ponadto z ustaleń dokonanych w tym sporze wynikało, że przez okres dwóch lat, w czasie kiedy pomiędzy stronami toczył się spór o wysokość należnej opłaty, pozwane stowarzyszenie bezprawnie korzystało z praw autorów, którymi zarządzała organizacja z.z. Ostatecznie zawarta umowa zobowiązywała stowarzyszenie do wnoszenia opłaty istotnie niższej niż ta, którą pierwotnie proponowała organizacja z.z., postulując wcześniej podpisanie nowej umowy licencyjnej. Sąd Najwyższy uznał, że wynosząca 2,8\% stawka opłat licencyjnych, którą stosowała organizacja z.z. w latach 2006-2008, była wysoka, o czym świadczy również to, iż aktualnie stawka ta wynosi tylko 2,2\% wpływów. Wynagrodzenie, którego trzykrotności żądała organizacja z.z., w obiektywnej ocenie ustalone zostało na poziomie wyższym niż przeciętny. Sąd Najwyższy uwzględnił także okoliczność, że ze względu na długość trwania procesu organizacji z.z. przysługują dodatkowo odsetki, których wysokość we wszystkich latach przewyższa wysokość odsetek od lokat bankowych. Z drugiej strony szkoda związana $\mathrm{z}$ naruszeniem praw autorskich sprowadza się przede wszystkim do utraconej opłaty, którą powód mógł uzyskać w latach 2006-2008, a która wynosiła 2,8\% przychodów, która to stawka była korzystniejsza od proponowanej przez profesjonalistów z Komisji Prawa Autorskiego oraz od stosowanej przez ostatnie lata przez powoda. W tych okolicznościach faktycznych Sąd Najwyższy stanął na stanowisku, że ubieganie się przez organizację z.z. o zapłatę na podstawie art. 179 ust. 1 pkt 3 lit. b u.p.a., w warunkach naruszenia majątkowych praw autorskich, przy wykorzystaniu przewidzianego przez tę normę tego swoistego ryczałtu, bez konieczności wykazywania ogólnych przesłanek odpowiedzialności odszkodowawczej w wymiarze wyższym niż jednokrotność stosownego wynagrodzenia, które w chwili dochodzenia byłoby należne tytułem udzielenia przez uprawnionego zgody na korzystanie z utworu, byłoby nieproporcjonalną sankcją o znamionach kary cywilnej, co nie dałoby się pogodzić z zasadą sprawiedliwości społecznej oraz równej ochrony praw majątkowych, ustanowionych przez ustawę zasadniczą. Sąd Najwyższy w swojej wypowiedzi, zawartej w motywach rozstrzygnięcia, podkreślił jednak, iż przyjęta przezeń prokonstytucyjna wykładnia tej normy prawa autorskiego jest bezpośrednio związana i jest formułowana w ścisłym związku z faktami ustalonymi w rozstrzyganej sprawie, a aktualizuje się ona wówczas, gdy dochodzona kwota ryczałtowa, odpowiadająca dwukrotności należnej opłaty licencyjnej, jest wyraźne i znacznie wyższa od rzeczywiście poniesionej przez autora, w wyniku działania naruszyciela, szkody.

Stan faktyczny sprawy, która stoi u podstaw pytania prawnego SN, jest odmienny, gdyż wynagrodzenie $z$ tytułu korzystania z praw autorskich nie ulegało zmianie w okresie, którego dotyczył spór, a tym bardziej uzgodniona między stronami umowy należność z tytułu praw autorskich nie uległa znacznemu obniżeniu, tak jak miało to miejsce w wyższej przedstawionej sprawie. 
1.7. Przyjęty w powyższym wyroku sposób argumentacji Sądu Najwyższego spotkał się z krytyką przedstawicieli doktryny, a także w samym orzecznictwie tego sądu. Jak trafnie zauważono, wiele tez mających charakter ogólny (nieodnoszących się stricte do stanu faktycznego), budzi wątpliwości oraz może być niewłaściwie zinterpretowanych, „w konsekwencji może to prowadzić do niewłaściwego rozumienia dyrektywy 2004/48/WE oraz wyroku TS z 25.01.2017 r., C-367/152 odnoszącego się do niniejszej sprawy. Skutkiem zaś takiej wykładni może być «pośrednie» (wynikające z wykładni) wyeliminowanie instytucji tzw. odszkodowania ryczałtowego uregulowanej w art. 79 ust. 1 pkt 3 lit. b. prawa autorskiego" (P.F. Piesiewicz, Prawo autorskie, autorskie prawa majatkowe, ochrona autorskich praw majątkowych, stosowne wynagrodzenie, naprawienie wyrzadzonej szkody. Glosa do wyroku SN z dnia 10 listopada 2017 r., V CSK 41/14, LEX nr 344970; zob. także P. Podrecki, Prawo autorskie, autorskie prawa majątkowe, ochrona autorskich praw majątkowych, stosowne wynagrodzenie, naprawienie wyrzadzonej szkody. Glosa do wyroku SN z dnia 7 grudnia 2017 r., V CSK 145/17, LEX nr 344971).

Równocześnie w literaturze przedmiotu zaaprobowano pogląd, zgodnie z którym istnieją obecnie podstawy pozwalające korygować model odszkodowań ryczałtowych. Przyjęto, że w konkretnej sprawie należy zawsze dokonać ustaleń co do wysokości rzeczywiście poniesionej szkody, jeżeli ma nastąpić ograniczenie wysokości dwukrotności odszkodowania ryczałtowego. Interes majątkowy w takim ustaleniu, w przypadku gdy powód domaga się zasądzenia odszkodowania ryczałtowego, ma pozwany, na którym powinien ciążyć również dowód, nie tylko wykazania rzeczywistej szkody, lecz również tego, że odszkodowanie ryczałtowe jest wyraźnie i znacznie wykraczające ponad rzeczywistą szkodę. „Sąd, któremu pozwany przedstawi wiarygodne dowody, może dopiero w takiej sytuacji dokonać odstępstwa od zasady dwukrotności odszkodowania ryczałtowego i ustalić kwotę odszkodowania, która może być i nawet wówczas wyższa od rzeczywistej szkody, ale nie może tej wysokości przekraczać nadmiernie. Sąd ma zatem możliwość korygowania wysokości odszkodowania ryczałtowego po wniesieniu przez pozwanego stosownych zarzutów i wniosków dowodowych [...] Z art. 13 ust. 1 lit. b dyrektywy należy wnosić, że jeśli sąd nie znajduje uzasadnienia dla wysokości odszkodowania ryczałtowego, może odmówić jego zasądzenia [...] odszkodowanie w modelu ryczałtowym nie jest należne bezwarunkowo i automatycznie. Badane powinny być zawsze przesłanki takich roszczeń w prawie krajowym. Powód, dowodząc naruszenia swoich praw, nie wykazuje wysokości rzeczywistej szkody, ale powinien przedstawić dowody na zasadność wysokości należnej opłaty lub wynagrodzenia. W ten sposób może być realizowana wykładnia oparta na dyrektywie 2004/48, w szczególności jej formuła, zgodnie z którą sąd zasądza odszkodowanie ryczałtowe, jeżeli uznaje za zasadne" (P. Podrecki, Prawo autorskie, op. cit.).

Odnotować należy także występujące w doktrynie zastrzeżenia co do możliwości domagania się przez uprawnionego z tytułu majątkowych praw autor- 
skich wielokrotności wynagrodzenia jako formy naprawienia szkody. Zdaniem niektórych autorów sankcja w postaci zasądzenia wielokrotności wynagrodzenia nie znajduje żadnego racjonalnego uzasadnienia ani z punktu widzenia prawnego, ani sprawiedliwościowego, łamiąc pryncypia odpowiedzialności odszkodowawczej w polskim prawie (zob. T. Targosz, A. Tischner, Dostosowanie polskiego prawa własności intelektualnej do wymogów prawa wspólnotowego. Uwagi na tle projektu z dnia 24 maja 2006 r. ustawy o zmianie ustawy o prawie autorskim i prawach pokrewnych oraz o zmianie innych ustaw, „Zeszyty Naukowe Uniwersytetu Jagiellońskiego" 2007, nr 1, s. 92 i n.). Zwrócono również uwagę, że ten sposób wynagrodzenia szkody może prowadzić do nadmiernej kompensacji poszkodowanego i z tego powodu łamać zasady prawa odszkodowawczego, w szczególności zasadę pełnego wynagrodzenia szkód oraz regułę ne quis ex damno suo lucrum faciat. Zastosowanie wielokrotności wynagrodzenia, jako forma „kary cywilnej” (zwłaszcza w razie naruszenia niezawinionego), nie jest zgodne z podstawowymi zasadami odpowiedzialności odszkodowawczej (zob. A. Nowicka, S. Sołtysiński, Uwagi o projekcie ustawy wdrażajacej dyrektywe 2004/48/WE w sprawie egzekwowania praw własności intelektualnej, „Kwartalnik Prawa Prywatnego" 2006, nr 4, s. 1069 i n.). Zauważa się, że absolutny (niezależny od winy i przesłanek egzoneracyjnych) charakter tego roszczenia, a zarazem ryczałtowe określenie jego zakresu, nadmiernie odrywają je od konstrukcji cywilnoprawnego odszkodowania. Wskazuje się, że ustawodawca posłużył się konstrukcją zbliżoną do roszczeń odszkodowawczych, chroniących słabszych uczestników obrotu (pracownika, konsumenta). Tymczasem prawnoautorskie, wielokrotne, zryczałtowane roszczenie odszkodowawcze ma przysługiwać także organizacji zbiorowego zarządzania czy użytkownikowi (nabywcy autorskich praw majątkowych lub licencjobiorcy wyłącznemu), a więc w istocie - podmiotowi mającemu niekiedy przewagę ekonomiczną nad naruszycielem, a na pewno nie co do zasady - słabszemu (zob. P. Żerański, Granica rygoryzmu podstawowych roszczeń czysto majątkowych w ochronie majątkowych praw autorskich, „Przegląd Prawa Handlowego” 2009, nr 8, s. 37). Podnosi się również, że sankcja w postaci możliwości żądania wielokrotności stosownego wynagrodzenia jest sprzeczna z przewidzianym w dyrektywie 2004/48/WE nakazem unikania odszkodowania o charakterze karnym (ang. punitive damages); (zob. pkt 26 preambuły dyrektywy 2004/48/WE; A. Drzewiecki [w:] Ustawa o prawie autorskim, op. cit.).

1.8. W kontekście powołanych podglądów przedstawicieli doktryny warto zauważyć, że Sąd Najwyższy w innych judykatach dotyczących tego zagadnienia stanowczo opowiedział się za możliwością skorzystania przez autora w warunkach naruszenia jego praw majątkowych do utworu z możliwości dochodzenia zryczałtowanego odszkodowania w wymiarze dwukrotności stosownego wynagrodzenia. W wyroku z 16 lutego 2017 r. (sygn. akt l CSK 100/16) SN stwierdził, że art. 79 ust. 1 pkt 3 lit. b u.p.a. nie wprowadza niedopuszczalnego odszkodowania o charakterze karnym ani nie narusza ogólnych zasad odpowiedzialności od- 
szkodowawczej, bowiem w wypadku odszkodowania ryczałtowego nie jest możliwe proporcjonalne uwzględnienie wysokości rzeczywistej szkody. Podkreślił ponadto, że zgodnie z art. $361 \S 2$ k.c. (przewidującym możliwość odstępstw od ogólnych zasad wynagradzania szkody), w przypadku braku odmiennego przepisu ustawy, można wprowadzić w ramach rozwiązań szczególnych inne zasady określania odpowiedzialności odszkodowawczej. Takim wyjątkiem od ogólnych reguł naprawienia szkody jest rozwiązanie przyjęte w prawie autorskim.

Z kolei w wyroku z 7 grudnia 2017 r. (sygn. akt. V CSK 145/17) Sąd Najwyższy stwierdził, że „Ze stanowiska zajętego przez Trybunał Sprawiedliwości Unii Europejskiej wprost wynika, że po pierwsze, postanowienia dyrektywy 2004/48/WE nie sprzeciwiają się krajowemu uregulowaniu odszkodowania za nielegalne wykorzystywanie cudzych majątkowych praw autorskich oraz, że art. 79 ust. 1 pkt 3 lit. b polskiego pr. aut. odpowiada postanowieniom dyrektywy. Jednocześnie, wbrew twierdzeniom skarżącego, wyrok Trybunału Konstytucyjnego za niezgodny z Konstytucją uważa tylko trzykrotne stosowne wynagrodzenie należne poszkodowanemu autorowi, uznając, że mając stanowić ryczałtowe odszkodowanie, nazwane przez przepis pr. aut. stosownym wynagrodzeniem jest zbyt wysokie i niesie w sobie, poza funkcją naprawienia szkody, swoistą karę, a więc spełnia nieprzewidzianą zasadami, rządzącymi prawem odszkodowawczym funkcję represyjną”. Sąd Najwyższy podkreślił również, że „danie możliwości ryczałtowego określenia wynagrodzenia upraszcza dochodzenie szkody, spełnia także funkcje prewencyjne odpowiedzialności odszkodowawczej i chroni uprawnionego we właściwym zakresie. Dwukrotność stosownego wynagrodzenia odpowiada w tej sytuacji poczuciu sprawiedliwości, a uznane za dopuszczalne przez orzecznictwo wewnętrzne sądów i Trybunału Konstytucyjnego oraz przez Trybunał Sprawiedliwości Unii Europejskiej, jako wynik porównania polskich rozwiązań normatywnych z prawem Unii Europejskiej znajduje aprobatę również w rozpoznawanej sprawie".

\section{- 2. Zarzut naruszenia art. 64 ust. 1 w związku z art. 31 ust. 3 w związku $z$ art. 2 Konstytucji}

2.1. Jak wskazuje przeprowadzona charakterystyka autorskich praw majątkowych, ustawodawca kształtując ich treść, oparł się na modelu ochrony własnościowej. Przy czym podkreśla się ich quasi-rzeczowy charakter, zdeterminowany naturą przedmiotu prawa autorskiego oraz wzajemną zależnością praw osobistych i majątkowych. W szczególności podkreśla się, że niematerialny charakter utworu stwarza „niemalże nieograniczone możliwości zwielokrotnienia dzieła” jak również możliwość jednoczesnego korzystania $\mathrm{z}$ tego samego dobra $\mathrm{w}$ ten sam sposób przez nieograniczoną liczbę ludzi (zob. wyrok TK z 23 czerwca 2015 r., sygn. akt SK 32/14). Z punktu widzenia regulacji konstytucyjnej ich ochrona opiera się na gruncie art. 64 ust. 1 i 2 Konstytucji. Trybunał przyjmuje, że autorskie prawa majątkowe ze względu na swą treść i funkcje są objęte gwarancjami konstytucyj- 
nymi, wynikającymi z art. 64 ust. 1 i 2. Intensywność tej ochrony, w zależności od rodzaju analizowanego problemu, może być identyczna lub zbliżona do prawa do ochrony własności bądź do ochrony innych praw majątkowych (zob. ibidem).

Jak podkreślił Trybunał Konstytucyjny, konstytucyjne prawo do ochrony własności oraz prawo do ochrony innych praw majątkowych jako publiczne prawo podmiotowe zawiera uprawnienia jednostki skierowane do państwa (tzw. ujęcie wertykalne). Ponadto TK wskazuje, że normatywna treść art. 64 ust. 1 i ust. 2 Konstytucji nie wyczerpuje się w relacji wertykalnej. Z punktu widzenia ustawy zasadniczej istotna jest także relacja horyzontalna, przewidziana wprost w art. 31 ust. 3 Konstytucji, w którym mowa jest o dopuszczalności ograniczania wolności i praw człowieka ze względu na konieczność ochrony praw innych osób. Trybunał najczęściej analizuje problemy związane z potrzebą ochrony w relacjach stricte wertykalnych, tzn. dotyczące nieuprawnionej ingerencji organów władzy publicznej. Natomiast gwarancje odnoszące się do sposobu ukształtowania relacji horyzontalnych dotyczą przede wszystkim ochrony przed ingerencją osób trzecich oraz instytucjonalizacji relacji między jednostkami w sferze praw majątkowych. Taki przypadek ma miejsce zarówno w sprawie o sygn. akt SK 32/14, jak i w sprawie, której dotyczy pytanie prawne. Kluczowym zagadnieniem jest zatem ustalenie „w jakim stopniu dopuszczalna jest ochrona majątkowych praw autorskich względem podmiotu, który te prawa narusza przy założeniu, że ingerencja w sytuację majątkową naruszającego jest również limitowana konstytucyjnie”. Podsumowując swoje wywody w tej części, TK stwierdził, że art. 64 ust. 1 i ust. 2 Konstytucji gwarantuje uprawnionemu z tytułu autorskich praw majątkowych swobodę dysponowania nimi oraz ochronę przed naruszeniami ze strony osób trzecich. Ochrona ta nie ma jednak charakteru absolutnego i jest limitowana konstytucyjnymi wymogami ochrony sytuacji majątkowej osoby dopuszczającej się naruszenia (zob. wyrok TK z 23 czerwca 2015 r., sygn. akt SK 32/14).

W ocenie Trybunału bezsporne jest, że autorskie prawa majątkowe są chronione, a ochrona ta jest konstytucyjnie uzasadniona. Podkreślił jednocześnie, że ustawodawca, dążąc do zapewnienia ochrony praw majątkowych przed ich naruszeniami, nie ma jednak pełnej swobody w określaniu stopnia tej ochrony. Nie może w sposób dowolny ingerować w sytuację majątkową sprawcy zachowania bezprawnego (deliktu). Nawet bowiem w stosunku zobowiązaniowym, u podstaw którego leży czyn niedozwolony, powinna znaleźć odzwierciedlenie zasada równości stron stosunku cywilnoprawnego. Mimo iż w sprawie, której dotyczy pytanie prawne, nie można mówić o podmiotach podobnych, którym przysługuje to samo prawo majątkowe, a tym samym nie jest uzasadnione odwoływanie się do wzorca kontroli zasady równości określonego w art. 64 ust. 2 Konstytucji, to zasada równości stron stosunku cywilnoprawnego ma znaczenie z perspektywy gwarancji konstytucyjnych. Wynikający z Konstytucji obowiązek ochrony praw majątkowych wymaga bowiem, aby strony stosunku cywilnoprawnego miały równorzędną pozycję, tj. dysponowały adekwatnymi do ich sytuacji in- 
strumentami ochrony. W wyroku sprawy o sygn. akt SK 32/14 Trybunał doszedł do wniosku, że zwiększony stopień ochrony przewidziany w zakwestionowanym mechanizmie - umożliwiającym dochodzenie odszkodowania w wysokości trzykrotności - stanowi jednak nadmierną ingerencję w wolność majątkową podmiotu naruszającego prawa autorskie. W ocenie Trybunału zakwestionowana wówczas regulacja zawiera „nadmiernie surową sankcję i zbyt głęboko wkracza w relacje horyzontalne między podmiotami toczącymi spór o prawa majątkowe”.

2.2. Wyrok TK z 23 czerwca 2015 r. (sygn. akt SK 32/14) przesądził zatem, że dochodzenie trzykrotności stosownego wynagrodzenia tytułem naprawienia szkody jest niedopuszczalne. Powyższe nie oznacza jednak zanegowania możliwości dochodzenia ryczałtowego odszkodowania per se. Ryczałtowy sposób określania odszkodowania w prawie autorskim został zaaprobowany przez Trybunał Konstytucyjny. Podobnie jak TSUE podkreślił on w przywołanym wyżej orzeczeniu, że idea ryczałtowego odszkodowania nie jest sprzeczna z zasadą ustalania konkretnej kwoty odszkodowania. Zasady ustalające wysokość odszkodowania przewidziane w art. 79 ust. 1 pkt 3 lit. b u.p.a. nie mogą zostać sprowadzone do reguł ogólnych wynikających z art. 361 k.c. Taki punkt widzenia oznaczałby, że ryczałtowa postać odszkodowania, jako stosowne wynagrodzenie, straciłaby logiczny sens. Wówczas do dochodzenia odszkodowania przez uprawnionego autora, którego prawa majątkowe zostały naruszone, niepotrzebne byłoby tworzenie szczególnego przepisu na ten temat w ustawie o prawie autorskim i prawach pokrewnych, a w razie niemożności ustalenia w toku procesu wysokości poniesionej szkody, wysokość odszkodowania mogłaby być określona na podstawie art. 322 k.p.c. (zob. wyrok SN z 7 grudnia 2017 r., sygn. akt V CSK 145/17).

Problem konstytucyjny, który wyłania się w niniejszej sprawie, dotyczy ochrony przeciwstawnych interesów majątkowych dwóch podmiotów prywatnych. Punktem wyjścia dla oceny zarzutu naruszenia art. 64 ust. 1 w związku $\mathrm{z}$ art. 31 ust. $3 \mathrm{i}$ w związku z art. 2 Konstytucji jest zatem wyważenie konkurencyjnych dóbr w układzie horyzontalnym. Należy wziąć pod uwagę zarówno prawo do ochrony własności przysługujące uprawnionemu z tytułu autorskich praw majątkowych, jak i wolność majątkową sprawcy deliktu. Trybunał przyjmuje, że „prima facie autorskie prawa majątkowe uprawnionego stoją w hierarchii konstytucyjnej wyżej niż wolność majątkowa naruszającego te prawa. Ta relacja pierwszeństwa nie ma jednak charakteru absolutnego. Rozstrzygając kolizję pomiędzy wskazanymi prawami, należy uwzględniać nie tylko wolność majątkową sprawcy deliktu, jak i dopuszczalne ograniczenia tej wolności uzasadnione ochroną praw autorskich, lecz także szereg okoliczności prawnych i faktycznych mających znaczenie dla testu proporcjonalności” (zob. wyrok TK z 23 czerwca 2015 r., sygn. akt SK 32/14).

Uwzględniając wytyczne Trybunału, w celu poszukiwania właściwego uzasadnienia kwestionowanej regulacji należy wskazać na pozycję stron stosunku cywilnoprawnego. Przyjmuje się, że uprawnienia stron powinny być równe, 
z uwzględnieniem charakteru łączącego strony stosunku prawnego. Zasada zapewnienia równości stron odnosi się do modelowego stosunku zobowiązaniowego, u podstaw którego leży umowa stron, nie może zostać wprost przeniesiona na inne rodzaje stosunków zobowiązaniowych. Wśród źródeł stosunku zobowiązaniowego wymienia się m.in. czyn niedozwolony. Stosunek zobowiązaniowy, jaki powstaje w związku z czynem niedozwolonym, nie jest rezultatem swobodnego wyrażenia woli przez strony tego stosunku. Jego treść stanowi obowiązek naprawienia szkody spowodowanej danym zdarzeniem, a u jego podstaw leży pewne ujemnie oceniane zachowanie danego podmiotu bądź inne zdarzenie, z zaistnieniem którego ustawodawca wiąże ten rodzaj odpowiedzialności (por. A. Olejniczak, Komentarz do art. 415 [w:] Kodeks cywilny. Komentarz, t. III, Zobowiązania - część ogólna, red. A. Kidyba, LEX nr 167898; B. Lackoroński, M. Raczkowski, Komentarz do art. 415 [w:] Kodeks cywilny, t. IIIA, Zobowiązania. Część ogólna, red. K. Osajda, 2017, Legalis, nb 9). Naruszenie własności lub innych praw majątkowych przez tego rodzaju działanie bezprawne (czyn niedozwolony) powoduje, że powstały stosunek zobowiązaniowy będzie charakteryzował się pewną specyfiką. Swoboda ustawodawcy w kształtowaniu mechanizmów ochrony stron tego stosunku nie jest zdeterminowana przez zasadę swobody umów - odnosi się ona bowiem wyłącznie do stosunków zobowiązaniowych, które mogą być kształtowane w drodze umowy. Jednocześnie ustawodawcę w tego rodzaju przypadkach w sposób szczególny legitymuje obowiązek zapewnienia ochrony praw majątkowych przed ich naruszeniami. Innymi słowy, bezprawne działanie danego podmiotu, wyrządzające szkodę innemu podmiotowi, samo w sobie daje prawodawcy podstawę do takiego ukształtowania pozycji zobowiązanego ex delicto, które będzie się wiązało $\mathrm{z}$ ingerencją w sferę przysługujących mu praw majątkowych. Nawet jednak w stosunku zobowiązaniowym, u podstaw którego leży czyn niedozwolony, powinna znaleźć odzwierciedlenie zasada równości stron stosunku cywilnoprawnego. Jednym ze środków ochrony w sprawach deliktowych, który jednocześnie umożliwia zachowanie równości stron tego stosunku, jest zapewnienie odszkodowania. Jednocześnie Trybunał dopuszcza, że w pewnych sytuacjach ustawodawca może jednak inaczej ukształtować zakres ochrony stron danego stosunku cywilnoprawnego. O ile, co do zasady, powinien zapewnić stronom równą ochronę i uwzględniać opisany wyżej podstawowy mechanizm odszkodowawczy, o tyle specyfika określonych deliktów może wymagać ustanowienia innych, szczególnych zasad ochrony podmiotu uprawnionego. To z kolei nie pozostaje bez znaczenia dla pozycji podmiotu zobowiązanego. Taka sytuacja ma miejsce $\mathrm{w}$ przypadku naruszenia autorskich praw majątkowych i wiąże się ze szczególnymi właściwościami tych praw. Jak wskazuje się w doktrynie, „dobra te (co do zasady w przeciwieństwie do rzeczy w znaczeniu wąskim) są niepowtarzalne i jednocześnie wszechobecne (tj. niezależne od czasu i miejsca, umożliwiając korzystanie z nich przez nieograniczony krąg osób). Podlegają też zwykle możliwości nieskończonego powielania i nie mogą być niczyje, a zatem 
nie podlegają zawłaszczeniu” (K. Zaradkiewicz, Instytucjonalizacja wolności majątkowej. Koncepcja prawa podstawowego własności i jej urzeczywistnienie w prawie prywatnym, Warszawa 2013, s. 409). W skazane wyżej cechy autorskich praw majątkowych po części przekładają się na potencjalną łatwość naruszania tych praw, jak również mogą się dla uprawnionego wiązać z trudnościami podczas dochodzenia rekompensaty z tytułu ich naruszenia.

2.3. Ponadto, przyjęte rozwiązanie wynika $\mathrm{z}$ charakteru odpowiedzialności cywilnej. Mimo że podstawową jej funkcją jest kompensacja szkody, nie jest to jedyna funkcja realizowana przez ten rodzaj odpowiedzialności.

Trybunał Konstytucyjny zwraca uwagę także na funkcję odstraszająco-prewencyjną, która nie niweluje podstawowej kompensacyjnej roli odpowiedzialności cywilnej. Konieczność taka powstaje ze względu na potrzebę ochrony praw własności intelektualnej z punktu widzenia realnego zagrożenia wystąpienia kolejnych deliktów. Jak zauważa TK w wyroku sprawy o sygn. akt SK 32/14, „W europejskim prawie kontynentalnym odszkodowanie pełni przede wszystkim funkcję kompensacyjną, co wiąże się z przyjęciem zasady niedopuszczalności wzbogacenia się poszkodowanego kosztem naruszyciela. Przyjęcie takiej perspektywy pozwala rozgraniczyć cywilną odpowiedzialność odszkodowawczą od odpowiedzialności służącej innym celom (w tym celom represyjnym). Tak pojmowanej cywilnej odpowiedzialności odszkodowawczej można przypisać także pewien prewencyjny wymiar”. W obrębie prawa własności intelektualnej pojawiają się jednak odstępstwa od przedstawionej wyżej zasady kompensacji, które „są zwykle uzasadniane trudnościami dowodowymi w wykazaniu przez uprawnionego poniesionego uszczerbku. Część przedstawicieli doktryny w sposób wyraźny łączy wprowadzanie tego rodzaju odstępstw ze specyfiką praw własności intelektualnej. Wskazują oni, iż w przypadku naruszeń tych praw «brakowi uszczerbków w majątku uprawnionego towarzyszyć mogą [...] korzystne zmiany w majątku naruszyciela, co nie jest typowe dla naruszeń dóbr materialnych. Choć możliwość osiągania korzyści z naruszenia nie jest wykluczona w przypadku rzeczy, jednakże sytuacja taka ma miejsce nieporównanie rzadziej niż w przypadkach naruszeń dóbr niematerialnych i jest sankcjonowana środkami ochrony prawnorzeczowej» (A. Tischner, Harmonizacja prawa polskiego z wymogami dyrektywy w sprawie egzekwowania praw własności intelektualnej - cz. II, „Monitor Prawniczy” nr 14/2005, s. 687-691)” (wyrok TK z 23 czerwca 2015 r., sygn. akt SK 32/14). W tym samym wyroku TK dodaje, że: „Możliwość uzyskania odszkodowania bez dokładnego ustalania wysokości poniesionej szkody sprzyja skutecznemu egzekwowaniu odpowiedzialności od sprawcy szkody. Instrumentowi, jakim dysponuje uprawniony, można także przypisać funkcję prewencyjną. Potencjalny sprawca szkody, który bez większych trudności mógłby naruszyć czyjeś autorskie prawo majątkowe, świadomy wprowadzonego przez ustawodawcę mechanizmu, ułatwiającego dochodzenie wysokiego odszkodowania, może powstrzymać się od bezprawnego działania”. 
Jak wskazano wyżej, w literaturze przedmiotu istnieją głosy krytyczne względem obecnie obowiązującego na gruncie ustawy o prawie autorskim i prawach pokrewnych modelu ryczałtowego odszkodowania, uprawniającego do wielokrotności wynagrodzenia, które byłoby należne tytułem udzielenia zgody na korzystanie z danego utworu. Podnosi się, że takie podejście ustawodawcy nie pokrywa się z koncepcją doskonałego odszkodowania, które powinno być ustalone na poziomie, przy którym poszkodowanemu jest obojętne, czy poniósł szkodę i otrzymał odszkodowanie, czy nie było szkody ani odszkodowania (zob. A. Nowak-Gruca, Cywilnoprawna ochrona autorskich praw majątkowych $w$ świetle ekonomicznej analizy prawa, Warszawa 2013, s. 261). Prezentowany pogląd uwzględnia jedynie perspektywę poszkodowanego. Zasady ustalania wysokości kompensacji szkody powinny jednak pozwolić ustalić odszkodowanie nie tylko w wysokości w pełni zadowalającej uprawnionego (czyli rekompensując w pełni uszczerbek powstały wskutek naruszeń jego praw), lecz także stanowić bodziec motywujący do podejmowania działań pożądanych społecznie, czyli polegających na przestrzeganiu zasad korzystania z cudzych utworów chronionych prawem autorskim.

Z jednej strony warto nawiązać do wypowiedzi przedstawicieli doktryny, którzy słusznie zwracają uwagę, że rolą prawa cywilnego nie jest w zasadzie pełnienie funkcji represyjno-prewencyjnej w ramach stosunków społecznych. Celem roszczeń prawa cywilnego jest przywrócenie równowagi interesów majątkowych w razie jej naruszenia, pełniąc przede wszystkim funkcję kompensacyjną. Z drugiej jednak strony nie można zaprzeczyć, że istotą każdej sankcji jest tkwiący w niej immanentny element prewencji, mający na celu zabezpieczenie poszanowania określonych wartości (M. Poźniak-Niedzielska [w:] M. Poźniak-Niedzielska, J. Szczotka, M. Mozgawa, Prawo autorskie i prawa pokrewne. Zarys wykładu, Bydgoszcz-Warszawa-Lublin 2007, s. 168).

Trafnie zwraca uwagę również SN w wyroku z 7 grudnia 2017 r., sygn. akt V CSK 145/17, że możliwość dochodzenia ryczałtowego odszkodowania na podstawie art. 79 ust. 1 pkt 3 lit. b u.p.a. „ograniczona do wartości jednokrotnego odpowiedniego wynagrodzenia (np. opłaty licencyjnej), oznaczałaby nie tylko brak uzyskania przez poszkodowanego pełnej rekompensaty szkody, ale stawiałaby w lepszej sytuacji prawnej sprawców naruszeń cudzych praw autorskich w stosunku do tych osób, które korzystają legalnie z twórczości autorskiej innych. W okolicznościach niniejszej sprawy oznaczałoby to, że przez wiele lat można by korzystać bezprawnie z cudzych praw autorskich, przy czym osoby nieuczciwe mogłyby liczyć, że to się w ogóle uda i nie poniosą żadnych konsekwencji, a jeśli już tak się nie stanie, to sankcją jest obowiązek zapłaty wyłącznie takiej należności, jaka wynikałaby dla sprawcy szkody z pierwotnej opłaty, i ewentualnie kosztów postępowania. Jak słusznie podnosi się, takie rozstrzygnięcie o istocie opłaty ryczałtowej oznaczałoby wobec korzystających z cudzych praw autorskich nieopłacalność zawierania przez nich umów licencyjnych [...] Danie możliwości ryczałtowego określenia wynagrodzenia upraszcza dochodzenie naprawienia 
szkody, spełnia także funkcje prewencyjne odpowiedzialności odszkodowawczej i chroni uprawnionego we właściwym zakresie. Dwukrotność stosownego wynagrodzenia odpowiada $\mathrm{w}$ tej sytuacji poczuciu sprawiedliwości, a uznane za dopuszczalne przez orzecznictwo wewnętrzne sądów i Trybunał Konstytucyjny oraz przez Trybunał Sprawiedliwości Unii Europejskiej, jako wynik porównania polskich rozwiązań normatywnych z prawem Unii Europejskiej znajduje aprobatę również w rozpoznawanej sprawie". Z powyższego wynika zatem nieefektywność rozwiązania, polegającego na zasądzaniu odszkodowań w wysokości równej opłacie licencyjnej, które dla podmiotu naruszającego oznaczałoby de facto jedynie odroczenie zapłaty tej kwoty. Takie rozwiązanie stałoby w sprzeczności z konstytucyjnym obowiązkiem ochrony praw majątkowych, z którego wynika konieczność stanowienia mechanizmów wykazujących się odpowiednią skutecznością.

2.4. Ograniczenie wysokości odszkodowania wyłącznie do jednokrotnej stawki niezapłaconego wynagrodzenia może wzbudzać poważne wątpliwości także $\mathrm{z}$ innych względów. Zasada pełnego odszkodowania wymaga bowiem wyrównania całości poniesionego uszczerbku, który w poszczególnych wypadkach może obejmować także inne, poza wynagrodzeniem, uszczerbki w dobrach prawnie chronionych uprawnionego. Tytułem przykładu w literaturze wskazuje się, że przy ustalaniu wysokości odszkodowania należałoby brać pod uwagę takie czynniki, jak: osłabienie pozycji uprawnionego na rynku, jego wyparcie z rynku, poniesienie kosztów adaptacji do warunków zaistniałych na rynku po naruszeniu, wytworzenia egzemplarzy dzieła, które w związku z naruszeniem stały się bezużyteczne, czy też samego wykrycia bezprawności (zob. A. Nowak-Gruca, Cywilnoprawna ochrona autorskich praw majątkowych, op. cit.). Ponadto w wypadku braku zawarcia umowy licencyjnej składnikami szkody uprawnionego z tytułu praw autorskich jest nie tylko wysokość tej opłaty, ale także koszty wykrycia sprawcy i dalsze koszty związane z prowadzonym postępowaniem. $Z$ tego względu szkoda w oczywisty sposób przewyższa samą opłatę licencyjną.

$\mathrm{Na}$ podobny zakres sumy składników odszkodowania zwraca się uwagę m.in. w motywie 26 preambuły dyrektywy 2004/48/WE, stanowiącym, że „W celu naprawy szkody, jaką właściciel prawa poniósł w wyniku naruszenia, którego dopuścił się naruszający wiedząc, że wchodząc w tę działalność dopuszcza się naruszenia, lub istnieją rozsądne podstawy domniemania, że wiedział o możliwości powstania takiego naruszenia, suma odszkodowań przyznanych właścicielowi praw powinna uwzględniać wszystkie właściwe aspekty, takie jak utrata przez właściciela dochodów lub nieuczciwy zysk uzyskany przez naruszającego oraz, gdzie właściwe, wszelki uszczerbek moralny, które posiadacz praw poniósł. Jako alternatywa, tam np., gdzie ustalenie sumy poniesionego uszczerbku byłoby trudne, sumę odszkodowań można oprzeć na elementach takich, jak opłaty licencyjne, honoraria autorskie lub opłaty, jakie byłyby należne, gdyby naruszający poprosił o zgodę na wykorzystanie wchodzących w grę praw własności intelektualnej. Nie jest celem wprowadzenie obowiązku zastosowania odszkodo- 
wań o charakterze kary, ale dopuszczenie rekompensaty opartej na obiektywnym kryterium przy uwzględnieniu wydatków poniesionych przez właściciela praw, takich jak koszty identyfikacji i badań” (EUR-Lex nr 32004L0048).

Podsumowując, należy stwierdzić, że kwestionowany przepis znajduje swoje uzasadnienie w bezprawności działania osoby dopuszczającej się naruszenia autorskich praw majątkowych. Naprawienie szkody poprzez wypłatę dwukrotności stosownego wynagrodzenia stanowi dla uprawnionego z tytułu praw autorskich skuteczny instrument ich ochrony. Spełnia tym samym kryterium pierwszego z testów proporcjonalności - celowości.

2.5. Natomiast z punktu widzenia kryterium niezbędności należy wskazać - za Trybunałem - że ingerencja w sferę praw majątkowych sprawcy deliktu, polegająca na możliwości uruchomienia przez podmiot uprawniony z tytułu autorskich praw majątkowych szczególnych środków ochrony, jest konieczna dla realizacji konstytucyjnie uzasadnionego celu ustawy. Ustawodawca, wprowadzając to roszczenie, uwzględnił specyfikę praw autorskich oraz popełnianych na ich tle deliktów. Ponadto TK wypowiadając się na temat możliwości żądania ryczałtowego odszkodowania, podkreślił, że „W ocenie Trybunału ukształtowanie przez ustawodawcę zryczałtowanego roszczenia odszkodowawczego prowadzi do ingerencji adekwatnej do charakteru tego czynu niedozwolonego i odpowiada wymogowi posłużenia się środkiem koniecznym dla realizacji konstytucyjnie uzasadnionego celu ustawy" (wyrok TK z 23 czerwca 2015 r., sygn. akt SK 32/14). Zdaniem TK odstępstwo od ogólnych zasad odpowiedzialności jest zatem uzasadnione.

2.6. Odpowiadając na pytanie, czy efekty wprowadzonej regulacji pozostają w odpowiedniej proporcji do nakładanych ciężarów, tj. czy cel, do którego dąży ustawodawca, można osiągnąć za pomocą środków równie skutecznych, ale mniej uciążliwych, należy ponownie wskazać, że z wyjątkiem roszczenia zawartego w kwestionowanej regulacji, przewidziane w art. 79 u.p.a. środki mają charakter obronny (zaniechanie naruszania, usunięcie skutków naruszenia) bądź wyrównawczy (naprawienie szkody na zasadach ogólnych, wydanie uzyskanych korzyści). Jak wcześniej wyjaśniono, przepis umożliwiający zasądzenie wielokrotności wynagrodzenia ma charakter szczególny. Jednym z argumentów za wprowadzeniem swoistych instrumentów ochrony majątkowych praw autorskich są trudności dowodowe związane właśnie ze wskazaniem rozmiaru szkody. W większości przypadków, nie mając dostępu do stosownych informacji i nie będąc w stanie wykazać faktycznych zależności między naruszeniem a szkodą, uprawniony nie ma możliwości udowodnienia swoich racji. Przede wszystkim z tego względu w przypadku naruszenia autorskich praw majątkowych wprowadzone zostało szczególne rozwiązanie. Obiektywne kryteria ustalenia wysokości odszkodowania polegają na zastosowaniu mierników, którymi mogą być średnia wartość rynkowa naruszonego prawa lub wartość innych, podobnych praw. Ustalenie w ten sposób odszkodowania jest oderwane od faktycznej wysokości szkody (zarówno w zakresie damnum emergens, jak i lucrum cessans), 
której w danym przypadku się nie bada. Odstąpienie od ustalenia rzeczywistej wielkości szkody jest zatem wynikiem niemożliwości lub ograniczeń w zastosowaniu metod opartych na zasadach ogólnych. Potrzeba wprowadzenia takich szczególnych rozwiązań jest generalnie związana z próbą wzmocnienia pozycji uprawnionego, który mając możliwość formułowania roszczeń odszkodowawczych na podstawie innych przesłanek niż zasady ogólne (bez potrzeby dowodzenia wysokości poniesionej szkody), zyskuje teoretycznie łatwiejszą możliwość dowodzenia okoliczności faktycznych. Co do zasady, wystarczające jest, że w takim wypadku odwoła się do faktu naruszenia i możliwego, a utraconego zysku z tytułu wynagrodzenia, które mógłby uzyskać.

Inny sposób obliczenia odszkodowania, chociaż różni się znacznie od modelu opartego na zasadach ogólnych, nie wynika jednak z odmiennych podstaw materialnoprawnych czy aksjologicznych. Wydaje się zatem, że możliwość dochodzenia wielokrotności wynagrodzenia, traktowana jako alternatywa $\mathrm{w}$ stosunku do innych roszczeń, jest następstwem dostrzeżenia, że w każdym przypadku bezprawnego korzystania z cudzego utworu naruszyciel co najmniej zaoszczędza wysokość wynagrodzenia. Bardzo często jednak, w wyniku dokonanego naruszenia, naruszyciel uzyskuje dodatkowe korzyści, wykraczające poza zaoszczędzone wynagrodzenie. Twórca może się oczywiście domagać wydania w pełnym rozmiarze korzyści uzyskanych z bezprawnej eksploatacji swojego utworu (art. 79 ust. 4 u.p.a.), wymaga to jednak także udowodnienia, że wspomniane korzyści zostały przez naruszyciela osiągnięte $\mathrm{w}$ dochodzonym rozmiarze. W praktyce okazuje się to w większości wypadków bardzo trudne, a najczęściej wręcz niemożliwe. Wprowadzenie powyższego mechanizmu podyktowane było dążeniem do uproszczonego, a zatem łatwiejszego i szybszego uzyskania ochrony i rekompensaty.

Należy zaznaczyć, że wspomnianych trudności dowodowych nie niweluje możliwość korzystania $\mathrm{z}$ takich środków jak roszczenie informacyjne (art. 47 u.p.a.). Roszczenie informacyjne ma charakter generalny i jest związane $\mathrm{z}$ dochodzeniem wszelkich wynagrodzeń i opłat. Może być dochodzone na drodze sądowej, co wymaga wystąpienia z odpowiednim powództwem (zob. uchwała SN z 17 września 2009 r., sygn. akt III CZP 57/09, która, choć dotyczy bezpośrednio art. 105 u.p.a., dała okazję do sformułowania poglądu, że dla roszczeń informacyjnych, takich jak wynikające $\mathrm{z}$ art. 47 u.p.a., właściwy jest tryb procesowy). Jego celem jest umożliwienie autorowi uzyskania informacji pozwalającej obliczyć lub zweryfikować wysokość wynagrodzenia należnego mu z tytułu eksploatacji utworu. W praktyce okazuje się jednak, że nie zawsze środki te są skuteczne. Żeby dochodzić dostępu do potrzebnych informacji, trzeba dysponować odpowiednią wiedzą i znajomością mechanizmów korzystania z utworu przez naruszyciela. Jest to często nieosiągalne, zwłaszcza dla indywidualnego twórcy, który występuje ze stosownym żądaniem wobec profesjonalnego użytkownika (np. producenta audiowizualnego, nadawcy, operatora sieci kablowej). Sformułowanie wniosku o udzielenie informacji wymaga ponadto ścisłego określenia rodzaju oczekiwa- 
nych informacji lub dokumentów. Na uprawnionym ciąży obowiązek uprawdopodobnienia faktu naruszenia, którego dotyczą żądane informacje, oraz wykazanie, iż informacje i dokumenty są niezbędne dla określenia wysokości dochodzonego wynagrodzenia. Ich skuteczność jest zatem - jak podnosi się w literaturze przedmiotu - bardzo ograniczona: „W przypadku naruszeń o bardziej skomplikowanej strukturze dotarcie do właściwych informacji wymaga znajomości mechanizmów korzystania z utworów w danym przypadku i uchwycenia (ocenienia) w ramach tych mechanizmów bezprawnie uzyskanych korzyści. Przykładem może być wykorzystanie utworu jako składnika w utworze audiowizualnym. Wskazanie roli, którą ten element miał w korzyściach z eksploatacji całości utworu audiowizualnego jest bardzo trudne" (J. Błeszyński, Ochrona majątkowych praw autorskich, op. cit., s. 850). Z jednej strony brak jest (jak zauważa sąd pytający) możliwości negocjowania stawek opłat licencyjnych $z$ organizacją z.z., z drugiej jednak ocenić trzeba, że w przypadku podmiotu bezprawnie korzystającego z utworu niezwykle utrudnione jest uniemożliwienie mu korzystania z przedmiotu ochrony praw autorskich. W innych okolicznościach podmiot oferujący usługi bądź towar może zrezygnować z dostarczania przedmiotu handlu kontrahentowi, który nie reguluje ciążących na nim należności. W przypadku dóbr chronionych prawami autorskimi ani twórca, ani organizacja z.z. nie dysponują środkami pozwalającymi na uniemożliwienie korzystania $z$ utworów audiowizualnych. Spowodowane jest to łatwością dostępu do utworów oraz ich kopiowania. Podmioty uprawnione z tytułu praw autorskich mają zatem poważnie utrudnioną możliwość zapobiegania działaniom powodującymi naruszenie ich praw.

W tej sytuacji nie można nie docenić znaczenia i efektywności możliwości domagania się wielokrotności wynagrodzenia, przykładowo, jako pozwalającej uniknąć trudności dowodowych alternatywy dla roszczenia o wydanie bezprawnie uzyskanych korzyści. Uwzględniając proces instytucjonalizacji ochrony autorskich praw majątkowych (na który wskazuje TK), należy stwierdzić, że nawet organizacje zarządzania zbiorowego nie są w stanie nadzorować, kontrolować i ujawniać każdego przypadku eksploatowania bez stosownych licencji utworów chronionych prawami autorskimi. Konieczne jest zatem istnienie rozwiązań skłaniających podmioty korzystające $z$ takich utworów do legalnego ich eksploatowania, bez konieczności dochodzenia roszczeń przez uprawnionych na drodze sądowej.

Odwołując się do wypowiedzi TSUE wyrażonej w wyroku z 25 stycznia 2017 r. (sygn. akt C-367/15), należy również przypomnieć o możliwości korygowania wysokości odszkodowania, jeżeli odszkodowanie ryczałtowe jest „wyraźnie i znacząco” wykraczające ponad rzeczywistą szkodę. Sąd, któremu pozwany przedstawi wiarygodne dowody, może w takiej sytuacji wyjątkowo dokonać odstępstwa od zasady dwukrotności odszkodowania ryczałtowego i ustalić kwotę odszkodowania, która może być i nawet wówczas powinna być wyższa od rzeczywistej szkody, ale nie może tej wysokości przekraczać nadmiernie (zob. powoływany już wyrok SN z 10 listopada 2017 r., sygn. akt V CSK 41/14). Odszkodowanie 
w modelu ryczałtowym nie jest zatem należne bezwarunkowo i automatycznie. Zgodnie z przytoczonymi motywami dyrektywy 2004/48/WE sprawca deliktu dysponuje zatem instrumentami umożliwiającymi mu obronę i zminimalizowanie ponoszonego uszczerbku majątkowego. Ponadto jego odpowiedzialność nie może „kilkukrotnie przewyższać” wyrządzonej szkody. Jej maksymalna wysokość zamyka się wielkością dwukrotności stosownego wynagrodzenia należnego tytułem udzielenia przez uprawnionego zgody na korzystanie $\mathrm{z}$ utworu.

Biorąc pod uwagę powyższe okoliczności, należy przyjąć, że ustawodawca dążąc do zapewnienia jak najpełniejszej ochrony uprawnionych z tytułu praw autorskich, nie naruszył zasady najłagodniejszego środka. Jak wykazano, brak jest równie skutecznego, ale mniej uciążliwego środka zapewniającego naprawienie szkody wyrządzonej przez naruszenie autorskich praw majątkowych, spełniającego również funkcje prewencyjne. Tym samym $\mathrm{z}$ analizy kontekstu normatywnego zakwestionowanej regulacji wynika, że spełnia ona test proporcjonalności sensu stricto.

2.7. Mając powyższe na uwadze, należy uznać, że kwestionowany przepis jest zgodny $\mathrm{z}$ art. 64 ust. $1 \mathrm{w}$ związku $\mathrm{z}$ art. 31 ust. $3 \mathrm{w}$ związku $\mathrm{z}$ art. 2 Konstytucji w zakresie, w jakim uprawniony, którego autorskie prawa majątkowe zostały naruszone, może żądać od osoby, która naruszyła te prawa, naprawienia wyrządzonej szkody przez zapłatę sumy pieniężnej w wysokości odpowiadającej dwukrotności stosownego wynagrodzenia, które w chwili jego dochodzenia byłoby należne tytułem udzielenia przez uprawnionego zgody na korzystanie $\mathrm{z}$ utworu.

Ponadto Sejm wnosi o umorzenie postępowania w pozostałym zakresie na podstawie art. 59 ust. 1 pkt 2 ustawy o TK ze względu na niedopuszczalność wydania wyroku.

\section{Bibliografia}

Barta J., Markiewicz R., Prawo autorskie i prawa pokrewne, Warszawa 2011.

Błeszyński J. Ochrona majątkowych praw autorskich na drodze cywilnej [w:] System prawa prywatnego, t. 13, Prawo autorskie, red. J. Barta, Warszawa 2017.

Bogdalski P., Środki ochrony autorskich praw majatkowych oraz ich dochodzenie $w$ świetle prawa polskiego, Kraków 2003.

Drzewiecki A. [w:] Ustawa o prawie autorskim i prawach pokrewnych. Komentarz, red. E. Ferenc-Szydełko, 2014, Legalis.

Ferenc-Szydełko E. [w:] Ustawa o prawie autorskim i prawach pokrewnych. Komentarz, red. E. Ferenc-Szydełko, Warszawa 2014.

Jankowska M., Komentarz do art. 79, teza 1 [w:] Ustawa o prawie autorskim i prawach pokrewnych. Komentarz, red. P. Ślęzak, 2017, Legalis.

Lackoroński B., Raczkowski M., Komentarz do art. 415 [w:] Kodeks cywilny, t. IIIA, Zobowiązania. Część ogólna, red. K. Osajda, 2017, Legalis. 
Machnikowski P., Funkcja prewencyjna roszczeń pieniężnych powstających $w$ razie naruszenia praw własności intelektualnej [w:] Spory o własność intelektualną. Księga jubileuszowa dedykowana Profesorom Januszowi Barcie i Ryszardowi Markiewiczowi, red. A. Matlak, S. Stanisławska-Kloc, Warszawa 2013.

Nowak-Gruca A., Cywilnoprawna ochrona autorskich praw majątkowych w świetle ekonomicznej analizy prawa, Warszawa 2013.

Nowicka A., Sołtysiński S., Uwagi o projekcie ustawy wdrażającej dyrektywę 2004/48/WE w sprawie egzekwowania praw własności intelektualnej, „Kwartalnik Prawa Prywatnego" 2006, nr 4.

Olejniczak A., Komentarz do art. 415 [w:] Kodeks cywilny. Komentarz, t. III, Zobowiązania - część ogólna, red. A. Kidyba, LEX nr 167898.

Piesiewicz P.F., Prawo autorskie, autorskie prawa majątkowe, ochrona autorskich praw majątkowych, stosowne wynagrodzenie, naprawienie wyrzadzonej szkody. Glosa do wyroku SN z dnia 10 listopada 2017 r., V CSK 41/14, LEX nr 344970.

Podrecki P., Komentarz do art. 79, teza 1 [w:] Bukowski M. i in., Prawo autorskie i prawa pokrewne. Komentarz, 2015, LEX nr 466622.

Podrecki P., Prawo autorskie, autorskie prawa majątkowe, ochrona autorskich praw majątkowych, stosowne wynagrodzenie, naprawienie wyrzadzonej szkody. Glosa do wyroku SN z dnia 7 grudnia 2017 r., V CSK 145/17, LEX nr 344971.

Poźniak-Niedzielska M. [w:] M. Poźniak-Niedzielska, J. Szczotka, M. Mozgawa, Prawo autorskie i prawa pokrewne. Zarys wykładu, Bydgoszcz-Warszawa-Lublin 2007.

Targosz T., Tischner A., Dostosowanie polskiego prawa własności intelektualnej do wymogów prawa wspólnotowego. Uwagi na tle projektu z dnia 24 maja 2006 r. ustawy o zmianie ustawy o prawie autorskim i prawach pokrewnych oraz o zmianie innych ustaw, "Zeszyty Naukowe Uniwersytetu Jagiellońskiego” 2007, nr 1.

Tischner A., Harmonizacja prawa polskiego z wymogami dyrektywy w sprawie egzekwowania praw własności intelektualnej - cz. II, „Monitor Prawniczy” 2005, nr 14.

Tischner A., Komentarz do zmiany art. 79 ustawy o prawie autorskim i prawach pokrewnych wprowadzonej przez Dz. U. z 2007 r. Nr 99 poz. 662 [w:] T. Targosz, A. Tischner, Komentarz do ustawy z dnia 9 maja 2007 r. o zmianie ustawy o prawie autorskim i prawach pokrewnych oraz niektórych innych ustaw, 2008, LEX nr 34672.

Tuleja P., Komentarz do art. 2 [w:] Konstytucja RP, t. I, Komentarz. Art. 1-86, red. M. Safan, L. Bosek, Warszawa 2016.

Tuleja P., Wpływ przesłanki funkcjonalnej na sposób rozpoznania pytania prawnego przez Trybunat Konstytucyjny, „Przegląd Sądowy” 2017, nr 6.

Wojtyczek K., Granice ingerencji ustawodawczej w sferę praw człowieka w Konstytucji RP, Kraków 1999.

Zaradkiewicz K., Instytucjonalizacja wolności majątkowej. Koncepcja prawa podstawowego własności i jej urzeczywistnienie w prawie prywatnym, Warszawa 2013.

Żerański P., Granica rygoryzmu podstawowych roszczeń czysto majątkowych w ochronie majątkowych praw autorskich, „Przegląd Prawa Handlowego” 2009, nr 8. 